This PDF is a selection from a published volume from the National Bureau of Economic Research

Volume Title: Trade in Services in the Asia Pacific Region, NBER East Asia Seminar on Economics (EASE), Volume 11

Volume Author/Editor: Takatoshi Ito and Anne O. Krueger, editors

Volume Publisher: University of Chicago Press

Volume ISBN: 0-226-38677-5

Volume URL: http://www.nber.org/books/ito_03-1

Conference Date: June 22-24, 2000

Publication Date: January 2003

Title: The Growth and Potential of Taiwan's Foreign Trade in Services

Author: Li-min Hsueh, An-loh Lin, Su-wan Wang

URL: http://www.nber.org/chapters/c10158 


\title{
The Growth and Potential of Taiwan's Foreign Trade in Services
}

\author{
Li-min Hsueh, An-loh Lin, and Su-wan Wang
}

\subsection{Introduction}

Taiwan's economy has performed remarkably well since 1951, growing at an annual average rate of 8.41 percent during the half-century period from 1951 to 1999, and foreign trade has undoubtedly played an important role in this remarkable growth rate. Taiwan's exports and imports of goods and services in real terms was only 16.9 percent of its gross domestic product (GDP) in 1951, but this share had increased steadily to 68.9 percent in 1981 and reached a staggering 95.7 percent in 1999, an extremely high percentage in comparison with many other countries.

Over the past two decades, as Taiwan has continued to maintain its high economic growth rate, there has also been rapid growth in Taiwan's foreign trade in services, with the domestic-service sector as a percentage of real GDP rising from 49.3 percent in 1971 to 56.8 percent in 1991, and reaching a peak of 62.9 percent in 1999 . Thus, the percentage of trade in services in real GDP, as given in the national income accounts, has increased from 11.3 percent in 1971 to 14.2 percent in 1991 and to 15.1 percent in 1999. This share of the services trade is expected to increase further in the future as Taiwan gains accession into the World Trade Organization (WTO) and its economy becomes fully liberalized and internationalized.

Still, the services trade has played a minor role in Taiwan's total trade and it has always been in deficit. The current status of Taiwan's services trade is closely related to Taiwan's developmental stage, which went through the peak of industrialization of the economy and reached the stage of expand-

Li-min Hsueh and Su-wan Wang are research fellows at the Chung-hua Institution for Economic Research, and An-loh Lin is a professor in the department of economics at Shih Hsin University. 
ing the economy's services sector in the mid-1980s. Government policies play an important role in the development of Taiwan's service sector. Before the mid-1980s, the government's industrial policies and its tax and financial incentive schemes were mainly directed toward manufacturing. Until the late 1980s, the scope of operation for several major service industries, such as banks, other financial institutions, highway passenger transportation, and air transportation, was restricted and new entries were only occasionally granted. Although Taiwan's service sector has grown rapidly in recent decades, its competitiveness is still weak.

To examine the past and future development of Taiwan's trade in services, this paper plans to (a) present a historic account of Taiwan's services trade and examine some of the factors responsible for its growth; (b) analyze the sources of growth of Taiwan's trade in producer services within the inputoutput framework; and (c) discuss the potential for future growth of Taiwan's services trade in the light of world trade developments.

The remainder of this paper is structured as follows: Section 5.2 examines the past development of the Taiwanese services trade, based on data from the national income accounts and some of their determinants. Section 5.3 analyzes Taiwan's producer import services and the sources of its growth based on data from the official input-output tables. Section 5.4 examines the trend in the services trade and discusses Taiwan's comparative advantage, based on data from its balance-of-payments statistics, with those of ten other developed and newly industrialized countries. It also provides a further examination of the trade in several specific services, including transportation, communications, and business services, and their potential for future development when Taiwan enters the WTO. Conclusions are drawn in Section 5.5.

\subsection{Taiwan's Trade in Services}

In this section, imports and exports of services are defined as covering all imports and exports except for those of goods valued on a free on board (f.o.b.) basis. They include such items as transport, warehousing, communication, insurance, financial services, business services, overseas travel, royalties and license fees, and other service items relating to imports or exports. The data available for this paper come from three sources: the National Income Statistics, input-output (I-O) tables, and the international balance-ofpayments (BOP) statistics. The National Income Statistics (DirectorateGeneral of Budget, Accounting, and Statistics, various issues) provide time-series data on the aggregate exports and imports of goods and services and on some crude components. The I-O tables (Directorate-General of Budget, Accounting, and Statistics, various issues) provide data on import services by the producing industry but only in intermittent years. The BOP statistics (Central Bank, various issues) contain annual information on a 
number of service items relating to imports or exports. Data from these three sources are not exactly in agreement with each other in terms of definition and coverage, and thus are not strictly comparable. Except for the aggregate data on the imports and exports of goods and services from the $\mathrm{Na}$ tional Income Statistics, the data are available only in current dollars and in units of local or U.S. currency, and these create problems of comparability over time if prices change. Despite all these deficiencies, the data from these three sources are analyzed in turn in the present and following sections.

\subsubsection{Import and Export Trends}

Table 5.1 lists separate annual data on Taiwan's imports and exports of goods and services, import and export service shares, and balance of trade in goods and services for the period 1951-99 and the average annual growth rates of these variables over each decade and over the whole period. Data are available on aggregate imports and exports for the components of goods and services in current and constant prices from the national income accounts (NIA), but merchandise transport (including storage and communication) and insurance charges, considered items of services, are included in the goods component and thus excluded from the services component. We have deducted these transport and insurance costs from the goods component and added them to the services component by using information on foreign transactions (available from the NIA for the years covering 198199) as well as information available from the BOP for the years prior to 1981. The resultant adjusted imports and exports and their services shares are listed in the first six columns. The next two columns are separate net exports for goods and services expressed in US\$ millions. The last two columns are shares of services based on the original, unadjusted data. These are given for a comparison of the movements of the service shares with or without inclusion of the merchandise transport and insurance in the service components. In addition, average annual growth rates for each item are given at the foot of the table for each decade from 1951 to 1999 and for the whole period.

Several observations can be made from table 5.1. First, Taiwan's services imports started with a much smaller base and grew faster on average than its goods imports. The average annual growth rate is 13.3 percent over the entire period 1951-99 for the former, as compared with 11.8 percent for the latter. Both growth rates have come down considerably in reflection of the slowing rate of overall economic growth over the last decade, with a 6.2 percent average growth rate obtained for the imports of services as compared with a higher growth rate of 8.5 percent reached for the imports of goods. The share of service imports rose from 12.4 percent in 1951 to 31.6 percent in 1985 , declined to 27.3 percent in 1986, and then by 1999 fell back to 20.8 percent - which remained 5 percentage points higher in comparison with the United States' share. The faster increase in the imports of goods relative 


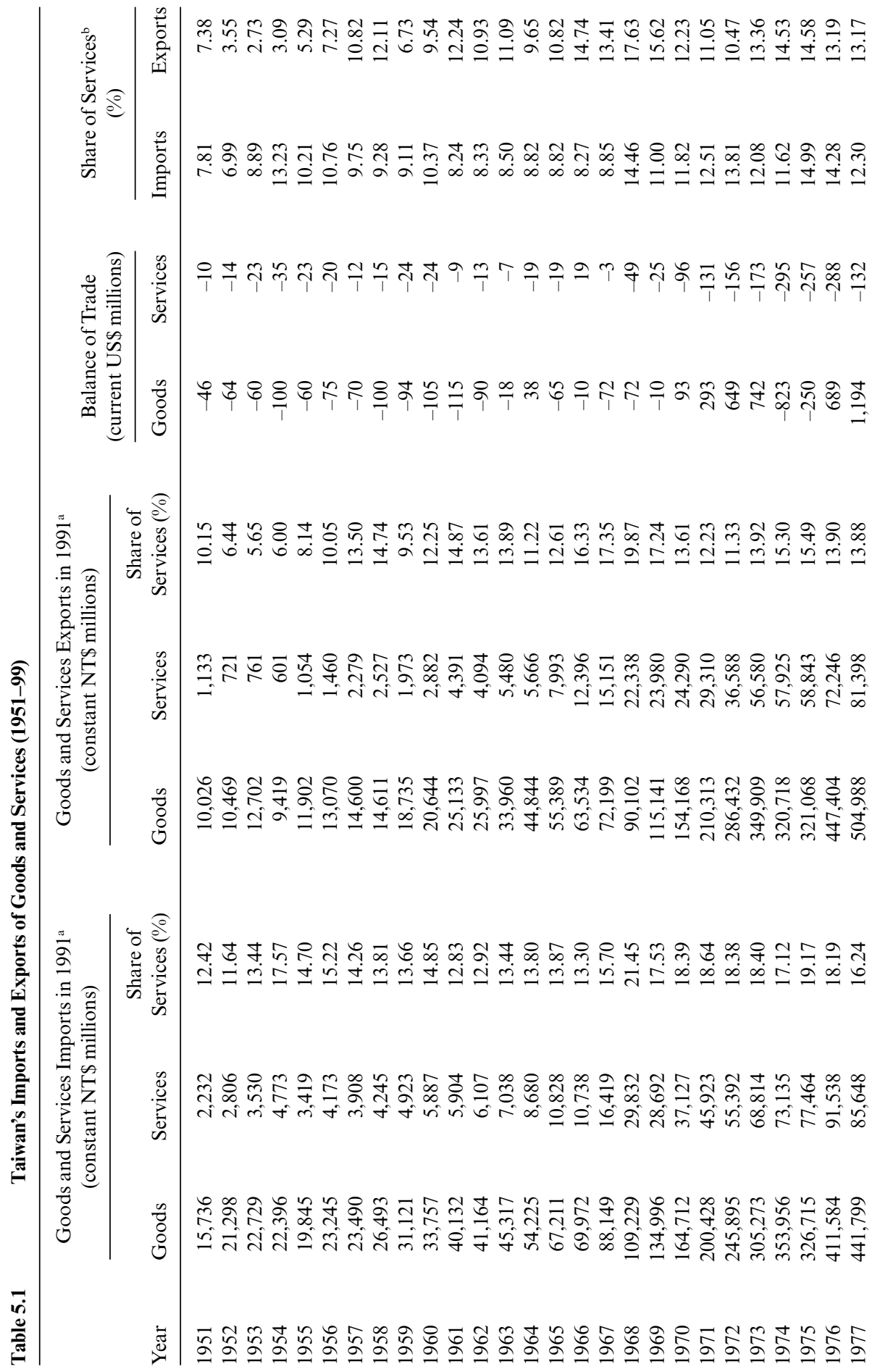


स 8 in

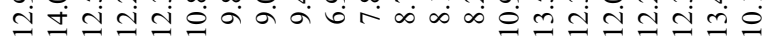

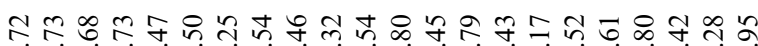

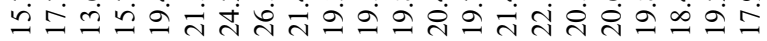

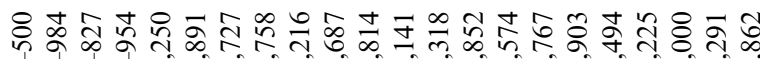
iी तै ती

तิ ㄱ-

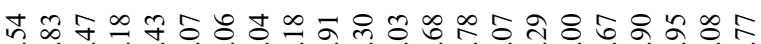

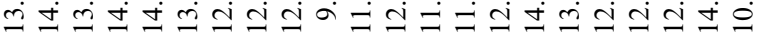

๘ 大்

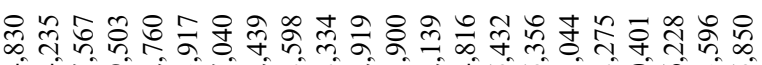

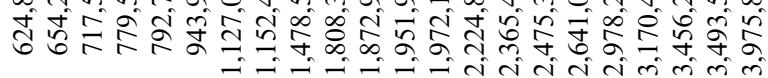

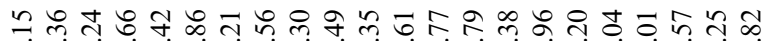
तิ તิळ

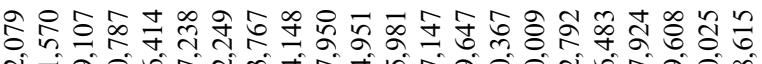

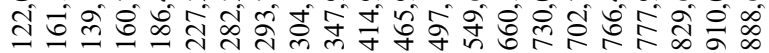

๓ t

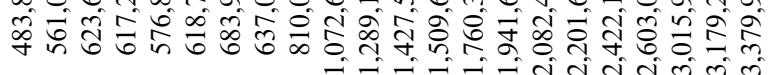

合\&
ิํㅇํำ

กุ๊

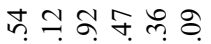

०ेंतें

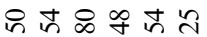

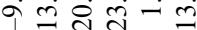

के ఫे 守= के - i

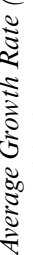

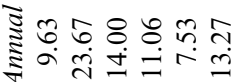
ทด์ลำ ¿

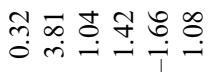

ํํำ 0 ป่

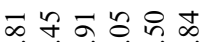
$\sigma \pm \Xi \dot{=}=$

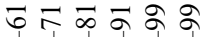

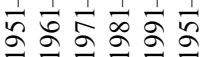


to that of services after 1985 resulted from a combination of factors, such as a strong recovery of the Taiwanese economy beginning in 1986, a substantial fall in the world prices of commodities, huge appreciation of the New Taiwan (NT) dollar, reductions of import duties, lessening of trade restrictions, upgrading of the industrial structure, and so on. These factors helped increase imports of consumption goods, materials, parts, and equipment more than imports of services.

Second, Taiwan's exports of services have been growing at 13.4 percent per year during the entire period, a rate close to the 13.3 percent for its exports of goods. Similar to the growth patterns of imports, the growth rates of exports have also slowed down over the last decade, having a 6.2 percent average growth rate for the exports of services as compared with an 8.5 percent growth rate for the exports of goods. The services share of exports fluctuated over the entire period. It was 10.2 percent in 1951 and attained 19.9 percent in 1968. The ratio has declined since then, however, and was only 10.8 percent in 1999 as compared with a much higher ratio of more than 28 percent for the United States.

Third, Taiwan is a small open economy and is dependent on foreign trade. Its trade position rather depends on the underlying comparative advantages combined with government policies, market structure, and changes in technologies. Net exports of goods have been in surplus since 1971, with the exception of the oil-crisis years 1974, 1975, and 1980, but the services-trade balance has been constantly in deficit ever since 1951, apart from a small positive figure in 1966. The average annual rate of change for the period 1951-99 was 13.3 percent for the former and -16.1 percent for the latter. The situation does seem to improve after 1991, with the average rate of increase in services-trade deficits declining to 6.4 percent for the last decade (from more than 20 percent for the previous two decades).

Fourth, when merchandise transport and insurance are excluded, the share of services in imports or exports has risen faster as opposed to the share when these items are included, as shown in the last two columns of table 5.1. That is, the imports and exports of other services have increased much faster than the freight and insurance cost of the merchandise imports and exports. During the period 1951-99 the share of these other services had increased by 1.8 percent per year over total imports and 0.7 percent per year over total exports, as compared with the corresponding shares of 1.1 percent and 0.1 percent with the inclusion of the merchandise freight and insurance cost. As table 5.2 shows, both insurance and freight, each as a percentage of the cost plus insurance and freight (c.i.f.) to Taiwan, have been falling since 1981 . The share of insurance had declined from 0.48 percent in 1981 to 0.31 percent in 1999, and the share of freight from 5.38 percent to 3.05 percent, over the same period. The declines are due partly to the falling shipping and insurance costs and partly to the locational shifts in imports and exports as trades between Taiwan and other Asian countries 
Merchandise Imports: Cost (f.o.b.), Insurance, and Freight

\begin{tabular}{|c|c|c|c|c|c|c|c|c|}
\hline \multirow[b]{2}{*}{ Year } & \multirow{2}{*}{$\begin{array}{c}\text { CIF } \\
\text { (US\$ millions) }\end{array}$} & \multirow{2}{*}{$\begin{array}{c}\text { FOB } \\
(\%)\end{array}$} & \multicolumn{3}{|c|}{ Insurance $(\%)$} & \multicolumn{3}{|c|}{ Freight $(\%)$} \\
\hline & & & Total & FF & DF & Total & $\mathrm{FF}$ & DF \\
\hline 1981 & 21,773 & 94.14 & 0.48 & 0.39 & 0.10 & 5.38 & 4.42 & 0.96 \\
\hline 1982 & 19,197 & 93.85 & 0.46 & 0.31 & 0.15 & 5.69 & 4.38 & 1.31 \\
\hline 1983 & 19,935 & 93.17 & 0.47 & 0.30 & 0.16 & 6.37 & 4.75 & 1.62 \\
\hline 1984 & 22,283 & 93.45 & 0.44 & 0.28 & 0.15 & 6.12 & 4.45 & 1.66 \\
\hline 1985 & 20,498 & 93.17 & 0.43 & 0.24 & 0.19 & 6.40 & 4.41 & 1.99 \\
\hline 1986 & 24,299 & 92.57 & 0.45 & 0.28 & 0.17 & 6.98 & 5.15 & 1.83 \\
\hline 1987 & 34,476 & 93.59 & 0.45 & 0.31 & 0.14 & 5.96 & 4.34 & 1.62 \\
\hline 1988 & 44,921 & 94.02 & 0.44 & 0.31 & 0.13 & 5.54 & 4.04 & 1.51 \\
\hline 1989 & 51,875 & 94.00 & 0.40 & 0.28 & 0.11 & 5.60 & 4.26 & 1.34 \\
\hline 1990 & 54,389 & 94.56 & 0.39 & 0.27 & 0.12 & 5.04 & 3.59 & 1.46 \\
\hline 1991 & 62,693 & 95.01 & 0.39 & 0.27 & 0.12 & 4.60 & 3.30 & 1.30 \\
\hline 1992 & 71,839 & 94.97 & 0.37 & 0.25 & 0.12 & 4.66 & 3.34 & 1.32 \\
\hline 1993 & 77,009 & 95.13 & 0.36 & 0.26 & 0.10 & 4.52 & 3.65 & 0.87 \\
\hline 1994 & 84,716 & 95.37 & 0.34 & 0.25 & 0.09 & 4.28 & 3.50 & 0.78 \\
\hline 1995 & 102,203 & 95.68 & 0.35 & 0.27 & 0.09 & 3.97 & 3.25 & 0.71 \\
\hline 1996 & 101,963 & 96.00 & 0.34 & 0.23 & 0.10 & 3.66 & 2.94 & 0.72 \\
\hline 1997 & 112,024 & 96.13 & 0.33 & 0.24 & 0.09 & 3.53 & 2.84 & 0.70 \\
\hline 1998 & 103,412 & 96.31 & 0.31 & 0.22 & 0.09 & 3.38 & 2.71 & 0.67 \\
\hline 1999 & 109,481 & 96.64 & 0.31 & 0.22 & 0.10 & 3.05 & 2.47 & 0.58 \\
\hline \multicolumn{9}{|c|}{ Annual Average } \\
\hline $1981-85$ & 20,738 & 93.55 & 0.45 & 0.30 & 0.15 & 6.00 & 4.48 & 1.52 \\
\hline 1986-90 & 41,992 & 93.85 & 0.42 & 0.29 & 0.13 & 5.73 & 4.20 & 1.53 \\
\hline 1991-95 & 79,692 & 95.28 & 0.36 & 0.26 & 0.10 & 4.36 & 3.40 & 0.96 \\
\hline 1996-99 & 106,720 & 96.27 & 0.32 & 0.23 & 0.10 & 3.41 & 2.74 & 0.67 \\
\hline
\end{tabular}

Source: National Income Statistics, Directorate-General of Budget, Accounting, and Statistics, Republic of China.

Note: $\mathrm{FF}=$ foreign firms; $\mathrm{DF}=$ domestic firms.

have increased substantially. Table 5.2 also indicates that the declines of both insurance and freight as a percentage of c.i.f. were greater for foreign firms than for domestic firms over the period.

\subsubsection{Determinants of Trade in Services}

Next, we examine the factors affecting the annual growth of Taiwan's trade in services for the period 1951-99, as reported above. In this regard the economic theory of demand for a commodity can be applied to explain the demand for imports of services as well as the demand for exports of services. Income or output and relative price are thus two typical determinants to be considered, and some other variables, such as trade in goods, industrial structure, and government policy, are also relevant. Our procedure is (a) to discuss the explanatory variables employed, (b) to conduct a unit root test, (c) to perform a regression analysis and cointegration test, and (d) to 
estimate the corresponding error-correction model. We deal with imports of services first and then with exports of services.

\section{Imports of Services}

To estimate the demand for imports of services, the explained variable is real imports of services (IMPS) as listed in table 5.1. These figures are computed from National Income Statistics to include the imports of merchandise transport and insurance services. The explanatory variables include per capita real national income, relative price of imports to domestic services, real imports of goods, GDP share of the service sector, and a liberalizationpolicy variable. The selection of each of these variables is discussed below in turn.

1. Per capita real national income (NIP). Imported services are purchased for intermediate or final use. The former refers to producer services and is affected by output, whereas the latter refers to final consumer services and is affected by income. An example is overseas trips. Higher income will induce more personal overseas trips and higher output will encourage more business trips abroad, and thus will increase imported services. Since income and output are closely related, we use income as an explanatory variable. Because NIP is a better measure of economic welfare and empirically performs better than total real national income, it is chosen as the income variable in our imports of services equation, with its data taken from National Income Statistics. NIP is expected to have a positive effect on IMPS.

2. Relative price of import to domestic services (RPIMPS). Many import and domestic services are substitutable and thus import services will be affected by their relative prices. We measure this variable by the ratio of the implicit deflator of IMPS to the implicit GDP deflator for the service sector. The two deflators are calculated from National Income Statistics. Because the price of import services will reflect changes in the foreign exchange rate, an appreciation of local currency will lower the price of imported services and thus will increase their demand. The sign of RPIMPS should be negative.

3. Imports of goods (IMPG). There are reasons that imports of goods will have a positive effect on imports of services. First, transport and insurance accompany shipments of goods; thus, more imports of goods increases the demand for transport and insurance services. Second, international businesses require communications, traveling, and financial services; thus, more imports of goods generates more demand for these services. Third, imports of equipment, materials, or finished goods may require importers to pay royalties, consultation fees, or assembly costs to foreign firms and thus may increase imported services. Fourth, trade in goods, a dominant component of foreign trade, can reflect the current status of an economy 
and constitutes a good proxy for the output variable, thus supplementing the use of the income variable given above. Although IMPS is closely related to IMPG, their relationship is found to be nonlinear. We thus add a quadratic term as an additional variable. IMPG, with data taken from National Income Statistics as listed in table 5.1, is expected to affect IMPS positively, but the effect of its square term is somewhat uncertain.

4. Share of the service sector (SS). This variable is used as a measure of the maturity of an economy in pursuit of economic development, which typically evolved from an agrarian economy to a manufacturing economy and then to a service economy. Taiwan has become a service economy since the mid-1980s, with SS now more than 60 percent. Expansion of the service sector should have a net negative effect on imports of services because more and more imported services would be replaced by domestic services. Whether shifts in Taiwan's industrial structure toward a service economy would have such an effect can be tested by the presence of the share variable. Data on SS in real terms, taken from National Income Statistics, are used.

5. Policy of liberalization (DETR). The government began to relax foreign exchange control and trade restrictions on goods and services in the mid-1980s and has continued this liberalization policy since then. Therefore, more and more financial and other services can be provided by foreign firms to domestic users, and this should increase imports of services. In order to measure the effect of the liberalization policy, we employ a proxy variable that equals zeros for the period 1951-85 and equals the effective tariff rate for the period 1986-99. The effective tariff rate, which is the ratio of import tariff revenues to custom imports of goods as computed from Tax Revenues Statistics (Ministry of Finance, various issues), has declined from 7.79 percent in 1986 to 2.82 percent in 1999 . The gradual declines of the effective tariff rate appear to mirror the increasing efforts of the government in its implementation of the liberalization policy. The sign of DETR should be negative because a smaller tariff rate means greater liberalization and thus more imports of services.

The explained variable and the explanatory variables, except SS and DETR, are expressed in log form. All of these variables are found to have a unit root according to the augmented Dickey-Fuller unit root tests as shown at the bottom of table 5.3. Two regressions are run and found cointegrated of order 1 based on the Phillips-Perron tests. The first regression contains NIP, RPIMPS, IMPG and its square, and SS, whereas the second includes the same set of explanatory variables plus the policy variable, DETR.

To summarize in equation form, the second equation is given by

$$
\begin{aligned}
\ln \left(\mathrm{IMPS}_{t}\right)= & i_{0}+i_{1} \ln \left(\mathrm{NIP}_{t}\right)+i_{2} \ln \left(\mathrm{RPIMPS}_{t}\right)+i_{3} \ln \left(\mathrm{IMPG}_{t}\right) \\
& +i_{4}\left[\ln \left(\mathrm{IMPG}_{t}\right)\right]^{2}+i_{5}\left(\mathrm{SS}_{t}\right)+i_{6}\left(\mathrm{DETR}_{t}\right)+u_{t}
\end{aligned}
$$




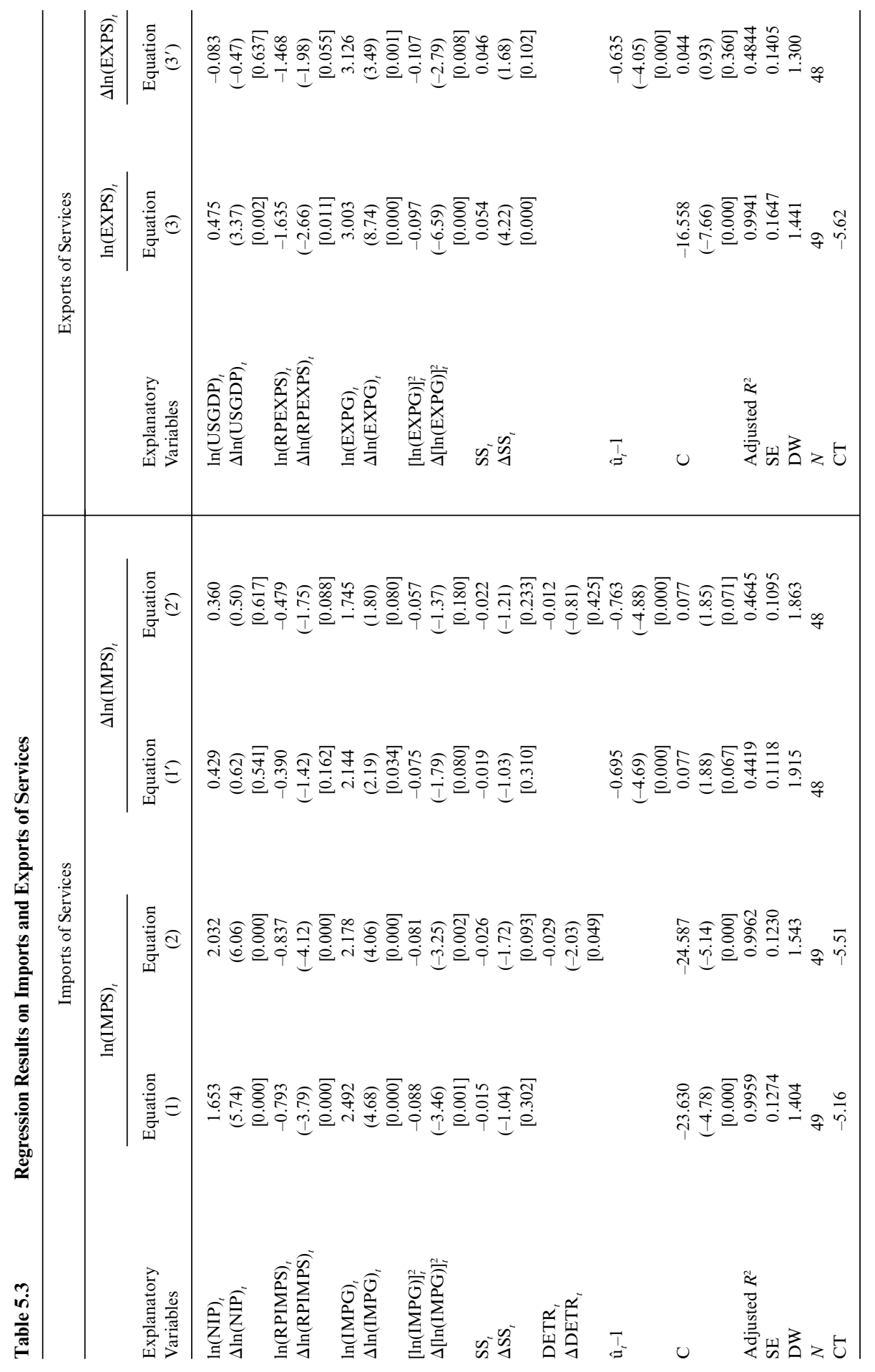




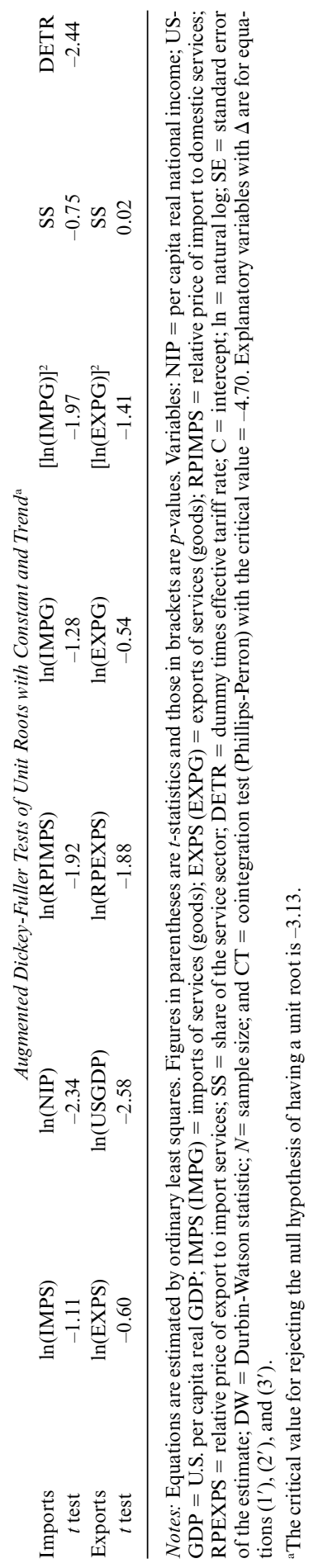


where IMPS is real imports of services; NIP is per capita real national income at factor cost; RPIMPS is relative price of import to domestic services; IMPG is real imports of goods; SS is real share of the service sector in GDP; DETR is a proxy variable for import liberalization, assuming zeros for the period 1951-85 and equal to the effective tariff rate for the period $1986-99 ; u$ is an error term; $t$ is the year; and $i_{1}>0, i_{2}<0, i_{3}>0, i_{4}=?(\leq 0$ or $\geq 0), i_{5}<0, i_{6}<0$. The first equation is the same as equation (1) without the policy variable DETR. These two equations are estimated by ordinary least squares (OLS) with the results reported in table 5.3.

Column (1) of table 5.3 shows that the sign of the income variable is positive and that of the price variable is negative, as expected, and both are statistically very significant. The estimated income elasticity is 1.65 and the price elasticity is -0.80 . Import of goods has a positive sign but its squared term a negative sign, implying that more imports of goods induces more imports of services but less proportionately. Share of the service sector has a negative effect on imports of services but the effect is not statistically very significant. Even so, the expansion of the service sector seems to have potential to replace part of the services imported. Addition of the policy variable appears to make the income and price effects larger and more significant. As indicated in column (2), the estimates of income and price elasticities become 2.03 and -0.84 , respectively, which clearly indicates that the imports of services are both income elastic and price inelastic. The effect of imports of goods has remained about the same and that of the service share becomes greater and more significant. The significant, negative sign of the policy variable, measured by the declining effective tariff rate, implies that liberalization has benefited imports of services. ${ }^{1}$

1. Our regression results indicate that using per capita real national income performs better than using total real national income in terms of $R^{2}, t$-statistic, and Durbin-Watson statistic. The two regressions are given below for a comparison:

\begin{tabular}{cccccccccc}
\hline & $\mathrm{C}$ & $\ln (\mathrm{Y})$ & $\ln (\mathrm{RP})$ & $\ln (\mathrm{IG})$ & {$[\ln (\mathrm{IG})]^{2}$} & $\mathrm{SS}$ & $\mathrm{DETR}$ & $R^{2} / \mathrm{SE}$ & $\mathrm{DW}$ \\
\hline Equation (2) & -24.6 & 2.032 & -0.837 & 2.178 & -0.081 & -0.026 & -0.029 & $0.9962 /$ & 1.543 \\
& & & & & & & & 0.1230 & \\
$t$-statistic & -5.76 & -6.06 & -4.12 & -4.06 & -3.25 & -1.72 & -2.03 & & \\
Equation (2') & -16.5 & 1.237 & -1.124 & 1.544 & -0.049 & -0.023 & -0.018 & $0.9959 /$ & 1.426 \\
$t$-statistic & -4.32 & 5.52 & -4.95 & 2.70 & -1.93 & -1.45 & -1.31 & & \\
\hline
\end{tabular}

where $\mathrm{Y}=$ per capita real national income in equation (2) but $=$ total real national income in equation $\left(2^{\prime}\right) ; \mathrm{RP}=$ relative price; $\mathrm{IG}=$ imports of goods; $\mathrm{SS}=$ real share of service sector; DETR = proxy for import liberalization policy; $R^{2} / \mathrm{SE}=$ adjusted $R^{2} /$ standard error of the estimate; and DW = Durbin-Watson statistic. It can be seen that using per capita real national income as the income variable has lower serial correlation than using total real national income and hence has a higher Durbin-Watson statistic and higher $t$-statistics for all the estimated coefficients except for the relative price. The overall fit is also better for the former than for the latter. 
The above two regressions, both of which are cointegrated of order 1 , show the long-run relationship between the imports of services and the four or five explanatory variables examined. To see their short-run relationship, two corresponding error-correction models are estimated and the results are presented in columns $\left(1^{\prime}\right)$ and $\left(2^{\prime}\right)$ of table 5.3. The explained variable is now in change in $\ln$ (IMPS) or the exponential growth rate in the imports of services, and its explanatory variables are also in change in each variable and include an error-correction term, which is the estimated OLS residual from column (1) or (2) lagged one period. The results indicate that the signs of the explanatory variables remain the same but their significances are considerably reduced. The sign of the error-correction term is negative and statistically very significant, with the estimated adjustment coefficient equal to -0.695 and -0.763 , respectively. Thus the short-run behavior of services imports appears to follow its long-run relationship with per capita income, relative service price, goods import, service-sector share, and government policy as its determinants.

\section{Exports of Services}

To estimate the demand for export services, the explained variable is real exports of services (EXPS) as listed in table 5.1, whose figures are computed from National Income Statistics to include the exports of merchandise transport and insurance services. The explanatory variables include per capita real U.S. GDP, relative price of export to import services, real exports of goods, and GDP share of the service sector, as discussed below.

1. Per capita real GDP of the United States (USGDP). This variable is used as a measure of per capita real income for the rest of the world because the United States has been the most important trade partner of Taiwan and has also played a very influential role in the world economy. The variable is the product of U.S. per capita nominal GDP and the real exchange rate between Taiwan and the United States. The latter is obtained by multiplying the nominal exchange rate (total of NT\$ per US\$) by the ratio of U.S. and Taiwanese GDP deflators. Since both per capita or total real U.S. GDP perform equally well empirically, either can be employed. However, to be in line with the import equation, per capita real U.S. GDP is used as the income variable in our export equation. The data are taken from the United States' Survey of Current Business (Department of Commerce, various issues), Statistical Abstract of the United States (Department of Commerce, various issues), and Taiwan's Financial Statistics (Central Bank, various issues) and National Income Statistics (Directorate-General of Budget, Accounting, and Statistics, various issues). The variable is expected to have a positive effect on Taiwan's exports of services.

2. Relative price of services between Taiwan and the rest of the world (RPEXPS). We use Taiwan's export price of services as a measure of the 
Taiwanese service price and Taiwan's import price of services as a measure of the world service price. Both prices are implicit deflators taken from $\mathrm{Na}$ tional Income Statistics. The price ratio has taken into account changes in the foreign exchange rate. Thus an appreciation of local currency will increase the price ratio by either lowering the import price in NT\$ or raising the export price in US\$. The effect of the relative price on Taiwan's exports of services is expected to be negative.

3. Exports of goods (EXPG). For the inclusion of exports of goods, reasons can be given similar to those for imports of services. First, services of transport and insurance accompany shipments of goods; thus, more exports of goods means greater demand for transport and insurance services, which can benefit domestic firms. Second, communications, traveling, and financial services go with international businesses; thus, more exports of goods generates more demand for these services. Third, exports of equipment, materials, or finished goods may require foreigners to pay royalties, consultation fees, or assembly costs to domestic firms, and thus may increase export services. The relationship between services export and goods export is found to be nonlinear as in the case of services imports. We thus add a quadratic term as an additional variable. EXPG, with data taken from National Income Statistics and listed in table 5.1, is expected to affect EXPS positively whereas the effect of its square term is more likely to be negative.

4. Share of the service sector (SS). This variable measures the developmental stage of an economy. As the domestic service sector expands, the capability of the domestic firms to serve exporters or importers should also expand. Expansion of the service sector, measured in real terms, is thus expected to have a positive effect on exports of services.

The explained variable and the explanatory variables (except SS) are expressed in $\log$ form. All of these variables are found to have a unit root according to the augmented Dickey-Fuller unit root tests as shown at the bottom of table 5.3. A regression containing $\ln ($ USGDP), $\ln$ (RPEXPS), $\ln (\mathrm{EXPG}),[\ln (\mathrm{EXPG})]^{2}$, and SS as the explanatory variables is run and found to be cointegrated of order 1 based on the Phillips-Perron tests. The equation is given by

$$
\begin{aligned}
\ln \left(\mathrm{EXPS}_{t}\right)= & e_{0}+e_{1} \ln \left(\mathrm{USGDP}_{t}\right)+e_{2} \ln \left(\mathrm{RPEXPS}_{t}\right) \\
& +e_{3} \ln \left(\mathrm{EXPG}_{t}\right)+e_{4}\left[\ln \left(\mathrm{EXPG}_{t}\right)\right]^{2}+e_{5}\left(\mathrm{SS}_{t}\right)+v_{t}
\end{aligned}
$$

where EXPS is real exports of services; USGDP is per capita real GDP of the United States; RPEXPS is relative price of export to import (world) services; EXPG is real exports of goods; SS is real share of service sector in GDP; $v$ is an error term; $t$ is the year; and $e_{1}>0, e_{2}<0, e_{3}>0, e_{4}=?(\leq 0$ or $\geq 0), e_{5}>0$. This equation is estimated by OLS and the results are given in column (3) of table 5.3. 
The result shows that the sign of the income variable is positive and that of the price variable is negative, as expected, and both are statistically very significant. The estimated income elasticity is 0.48 and the price elasticity is -1.64 in contrast to 2.03 and -0.84 for the case of service imports. Thus Taiwan's exports of services are income inelastic but price elastic, whereas its imports of services are income elastic but price inelastic. This finding may explain in part why Taiwan's trade balance in services has been in deficit for the last fifty years. Signs of the exports of goods and its square are significantly positive and negative, respectively, as their counterpart on the imports of services, with the estimated values of the square term roughly the same. Thus more exports of goods induces more exports of services but less proportionately. Share of the service sector has a significant positive effect on exports of services, whereas it has a negative effect on imports of services. Growth of the service sector will thus help reduce the deficits of trade in services. ${ }^{2}$

The regression, which is cointegrated of order 1, shows the long-run relationship between the exports of services and the four explanatory variables examined. To illustrate their short-run adjustment relationship we estimate the corresponding error-correction model; the results are presented in column (3') of table 5.3. The explained variable is now in change in $\ln ($ EXPS) or the exponential growth rate in the exports of services, and its explanatory variables are also in change in each variable in equation (2) and include an error-correction term, which is the estimated OLS residuals from equation (2) lagged one period. The results indicate that signs of the explanatory variables remain the same and significant except for $\Delta \ln ($ USGDP), which becomes negative but statistically insignificant. The short-run effect of income is thus almost nil but the effects of other variables remain intact. Sign of the error-correction term is negative and statistically significant

2. The two regressions based on per capita or total real GDP of the United States are given below for a comparison:

\begin{tabular}{ccccccccc}
\hline & $\mathrm{C}$ & $\ln (\mathrm{Y})$ & $\ln (\mathrm{RP})$ & $\ln (\mathrm{XG})$ & {$[\ln (\mathrm{XG})]^{2}$} & $\mathrm{SS}$ & $R^{2} / \mathrm{SE}$ & $\mathrm{DW}$ \\
\hline Equation (3) & -16.6 & 0.475 & -1.635 & 3.003 & -0.097 & 0.054 & $0.9941 /$ & 1.441 \\
& & & & & & & 0.1647 & \\
$t$-statistic & -7.66 & 3.37 & -2.66 & -8.74 & -6.59 & 4.22 & & \\
Equation (3') & -18.1 & 0.462 & -1.690 & 2.896 & -0.093 & 0.052 & $0.9942 /$ & 1.434 \\
$t$-statistic & -8.55 & 3.58 & -2.78 & 8.33 & -6.38 & 4.09 & & \\
\hline
\end{tabular}

where $\mathrm{Y}=$ per capita real USGDP in equation $(3)$ but $=$ total real USGDP in equation $\left(3^{\prime}\right)$; $\mathrm{RP}=$ relative price; $\mathrm{XG}=$ exports of goods; $\mathrm{SS}=$ real share of service sector; $R^{2} / \mathrm{SE}=$ adjusted $R^{2} /$ standard error of the estimate; and DW $=$ Durbin-Watson statistic. It can be seen that using per capita real USGDP as the income variable has a slightly higher Durbin-Watson statistic but slightly lower adjusted $R^{2}$ than using total real USGDP. The estimates of coefficients are about the same in terms of size and significance. Therefore, both perform about equally well and either one can be employed as the income variable in our export equation. 
with the estimated adjustment coefficient equal to -0.635 . The short-run behavior of services import appears to follow its long-run relationship with per capita world income, relative service price, goods export, and servicesector share as its determinants.

We conclude this section by pointing out that domestic or world income, relative price of services, trade in goods, and a country's service sector are four important determinants of the trade in services found in our regression analysis. Besides, government liberalization policies can play an important role in importing services.

\subsection{Taiwan's Imports of Producer Services from Input-Output Tables}

Input-output tables provide another source of data on Taiwan's imports and exports of services for analysis, but they are available only on an intermittent basis. In this section, we shall first summarize the information on Taiwan's imports and exports of goods and services in a sequence of fiveyear intervals covering the years 1966, 1971, 1976, 1981, 1986, 1991, and 1996. ${ }^{3}$ We then focus on the imports of producer services in the framework of I-O tables ${ }^{4}$ and decompose changes in the total imports of producer services between 1986 and 1991 and between 1991 and 1996 to examine the sources of the changes in terms of changes in I-O coefficients, in final demands, and in economic growth.

\subsubsection{Trade Statistics from the Input-Output Tables}

Table 5.4 provides a summary of statistics on the import and export of goods and services tabulated from the officially available I-O tables. The goods and services components of the imports are each listed by intermediate and final use, and net exports are given for goods and services. The amount, share, and growth are shown separately for the listed items; the amount is recorded in US\$ millions converted from the local currency by use of the prevailing exchange rate. The share is nominal, but calculation of growth is based on local currency in real terms. Although the figures are given only for 1966, 1971, 1976, 1981, 1986, 1991, and 1996-and thus would be affected by the economic conditions of those particular yearsthe data over a thirty-year time span should display a general tendency of the growth of Taiwan's trade in goods and services.

Several observations can be made from the table. First, total imports of services has increased faster than total imports of goods. The annual rate of growth was 16.6 percent for the former and 11.8 percent for the latter over the entire period 1966-96. This was also the case for the imports of services

3. Input-output data are compiled based on censuses conducted independently every five years.

4. Producer services are defined as services that are used for production by the producing sectors of the economy. 


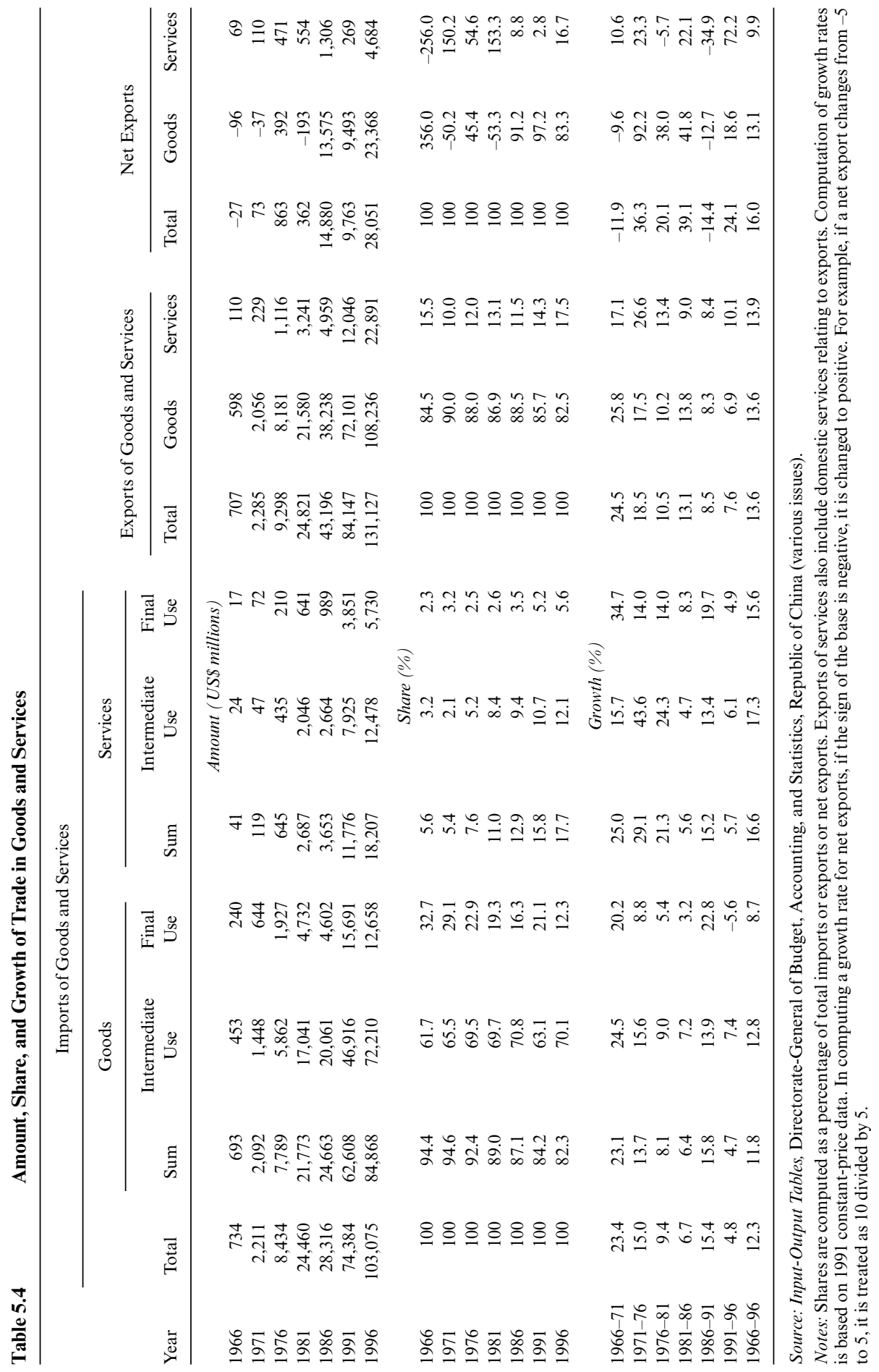


in intermediate or final use. Over the same period, the imports of producer and final services had grown 17.3 percent and 15.6 percent per year, respectively, as compared with the annual growth rates of 12.8 percent and 8.7 percent for the imports of intermediate and final goods. The growth in the imports of services was faster because it started from a base much lower than the imports of goods.

Second, the share of total imported services rose from 5.6 percent in 1966 to 17.7 percent in 1996. In particular, the imports of producer services as a percentage of the total imports of goods and services increased from 3.2 percent in 1966 to 12.1 percent in 1996, and the import share for final services rose at a slower rate, from 2.3 percent to 5.6 percent. Thus the percentage of imported producer services in total imported services increased from 58 percent in 1966 to 68 percent in 1996 as the share of imported consumption services decreased.

Third, the declining share of merchandise imports from 94.4 percent to 82.3 percent between 1966 and 1996 resulted mainly from the decline in final use, which fell from 32.7 percent in 1966 to 12.3 percent in 1996. The share of imported goods for production actually rose from 61.7 percent in 1966 to 69.5 percent in 1976, and then remained steady at 70.1 percent in 1996. If the goods and services components for intermediate use are combined, the share was 64.9 percent in 1966 and 82.2 percent in 1996. All these figures reflect the fact that the Taiwanese economy has increasingly depended on imports of intermediate inputs for production while the imports of goods for final use have gradually been substituted by domestic final goods.

Fourth, the exports of goods increased by 13.6 percent per year during 1966-96, a rate slightly below the 13.9 percent annual rate of increase for the exports of services. It is noted that domestic services that come as a result of the exports of goods, such as transport services to ports and exportrelated financial services, are treated as the exports of services in the I-O tables, contrary to the convention of national income accounting, which treats export-related inland services as part of the f.o.b. cost of the goods shipped abroad. This is why the net exports of services, as shown in the final column of table 5.4, are positive and not negative as seen in table 5.1.

The figures in tables 5.1 and 5.4 are therefore not strictly comparable due to the above-mentioned definitional problem, and also due to the differences in the units (i.e., real NT \$ or nominal US\$) used in the two tables. The imports and exports of services in table 5.1 are in local currency expressed in constant prices, and their shares are in real terms. These items in table 5.4 are calculated in current prices and in US\$. However, the shares in both tables moved in tandem. For example, in table 5.4 the share of import services in 1966 was 5.6 percent (in nominal terms), but in table 5.1 this was 13.3 percent (in real terms), and these shares were 17.7 percent and 23.0 percent respectively, in 1996. In spite of the differences, they had all moved upward and maintained roughly the same level of disparity. However, the 
share of export services in table 5.4 had moved up from 15.5 percent in 1966 to 17.5 percent in 1996, while there was a fall in table 5.1 from 16.3 percent to 12.9 percent between 1966 and 1996, partly due to the definitional problem just mentioned.

Finally, we note that Taiwan has been well known for its development of hi-tech industries and its strong showing in the exports of hi-tech products, but its exports of hi-tech information services are still very limited. Statistics from the I-O tables show that the exports of hi-tech products, such as computer products, computer peripheral equipment, data-storage media, and computer components, were US\$7,364 million in 1991 and US\$15,965 million in 1996, and the corresponding imports were US\$7,250 million in 1991 and US\$1,474 million in 1996, resulting in a trade surplus of US\$114 million in 1991 and US\$14,491 million in 1996. The exports of hi-tech information services, including software designs, on the other hand, were US\$259 million in 1991 and US\$393 million in 1996; the corresponding imports were US\$458 million in 1991 and US\$712 million in 1996, yielding a trade deficit of US\$199 million in 1991 and US\$319 million in 1996. This is again an indication of weak showing for Taiwan's trade in services.

\subsubsection{Decomposition of Growth in Total Imported Producer Services}

The total amount of services imported by all industries for intermediate use, which is defined as producer service imports, was NT $\$ 54,867$ million in 1986, NT\$213,177 million in 1991, and NT\$292,996 million in 1996, all in 1991 constant dollars. This increased on average by 31.2 percent per year over the period 1986-91 and 6.6 percent per year over the period 1991-96. In order to examine the causes of changes in these two periods, the amount of increase during each period is decomposed into several sources based on I-O tables and on an equation derived from Han (1995).

\section{The Model}

The decomposition for a vector of imported producer goods and services is given by

$$
\begin{array}{rlrl}
\Delta \mathbf{S}= & \left(\mathbf{M}_{\mathbf{t}}-\mathbf{M}^{*}\right) R_{0} \mathbf{Y}_{\mathbf{D} \mathbf{0}} & & \text { (import substitution effect) } \\
& +\left(\mathbf{M}^{*}-\mathbf{M}_{\mathbf{0}}\right) R_{0} \mathbf{Y}_{\mathbf{D} \mathbf{0}} & & \text { (changes in import intensity) } \\
& +\mathbf{M}_{\mathbf{0}}\left(R_{t}-R_{0}\right) \mathbf{Y}_{\mathbf{D} \mathbf{0}} & & \text { (changes in intermediate } \\
& +\left(\mathbf{M}_{\mathbf{t}}-\mathbf{M}_{\mathbf{0}}\right)\left(R_{t}-R_{0}\right) \mathbf{Y}_{\mathbf{D} \mathbf{0}} & & \text { (interaction effect) } \\
& +\mathbf{M}_{\mathbf{0}} R_{0}\left(\mathbf{y}_{\mathbf{t}}^{\mathbf{c}}-\lambda^{c} y_{0}^{c}\right) & & \text { (effect of changes in } \\
& +\mathbf{M}_{\mathbf{0}} R_{0}\left(\mathbf{y}_{\mathbf{t}}^{\mathbf{g}}-\lambda^{g} y_{0}^{g}\right) & & \text { consumption) } \\
& & & \text { (effect of changes in } \\
& \text { government expenditure) }
\end{array}
$$




$$
\begin{aligned}
& +\mathbf{M}_{0} R_{0}\left(\mathbf{y}_{\mathbf{t}}^{\mathbf{i}}-\lambda^{i} y_{0}^{i}\right) \quad \text { (effect of changes in } \\
& +\mathbf{M}_{0} R_{0}\left(\mathbf{y}_{\mathbf{t}}^{\mathrm{iv}}-\lambda^{i v} y_{0}^{i v}\right) \quad \text { (effect of changes in stock } \\
& \text { change) } \\
& +\mathbf{M}_{0} R_{0}\left(\mathbf{y}_{\mathbf{t}}^{\mathrm{e}}-\lambda^{e} y_{0}^{e}\right) \quad \text { (effect of changes in export) } \\
& +\mathbf{M}_{0} R_{0} \mathbf{Y}_{\mathbf{D} 0}(\tilde{\lambda}-\tilde{\theta}) \quad \text { (effect of changes in final } \\
& \text { demand component structure) } \\
& +\mathbf{M}_{\mathbf{0}} R_{0}(\theta-1) \mathbf{Y}_{\mathbf{D} 0} \quad \text { (economic growth) } \\
& +\left(\mathbf{M}_{\mathbf{t}} R_{t}-\mathbf{M}_{\mathbf{0}} R_{0}\right)(\theta-1) \mathbf{Y}_{\mathbf{D} 0} \quad \text { (growth multiplied by } \\
& \text { technical change effect) } \\
& +\left(\mathbf{M}_{\mathbf{t}} R_{t}-\mathbf{M}_{\mathbf{0}} R_{0}\right)\left(\mathbf{Y}_{\mathbf{D t}}-\theta \mathbf{Y}_{\mathbf{D} \mathbf{0}}\right) \quad \text { (effect of interaction between } \\
& \text { technical change and changes } \\
& \text { in final demand structure) }
\end{aligned}
$$

where $\mathbf{S}$ is a subtotal imported goods and services demand vector by categories $(\mathrm{m} \times 1)$ measured in value; $\mathbf{M}$ is an import coefficient matrix by goods and services and by sector $(\mathrm{m} \times \mathrm{n})$ with the coefficients measured in terms of value required per unit output; $\mathbf{M}^{*}=\mathbf{M}_{\mathbf{0}}(\widehat{\mathbf{u M}})(\widehat{\mathbf{u M}})^{-1}$ with $\mathbf{u}$ being a unit row vector $(1 \times \mathrm{m})$ and $\left({ }^{\wedge}\right)$ denoting the diagonal matrix of the vector in the parentheses; $\mathbf{Y}_{\mathbf{D}}$ is a final domestic demand vector $(\mathrm{n} \times 1)$ measured in value terms and $\mathrm{R}=(\mathbf{I}-\mathbf{D})^{-1}$ with $\mathbf{D}$ being a domestic technical coefficient matrix $(n \times n)$ measuring the input requirements per unit output in value terms; and $\mathbf{I}$ is an identity matrix $(\mathrm{n} \times \mathrm{n}) . \theta=\mathrm{TDP}_{t} / \mathrm{TDP}_{0}$ is the expansion rate of the total domestic product (TDP) between any two years. Moreover,

$$
\lambda^{c}=\frac{\boldsymbol{\mu} \mathbf{y}_{\mathbf{t}}^{\mathrm{c}}}{\boldsymbol{\mu} \mathbf{y}_{\mathbf{0}}^{\mathrm{c}}}, \quad \lambda^{g}=\frac{\boldsymbol{\mu} \mathbf{y}_{\mathbf{t}}^{\mathbf{g}}}{\boldsymbol{\mu \mathbf { y } _ { \mathbf { 0 } } ^ { \mathbf { g } }}}, \quad \lambda^{i}=\frac{\boldsymbol{\mu} \mathbf{y}_{\mathbf{t}}^{\mathrm{i}}}{\boldsymbol{\mu \mathbf { y } _ { \mathbf { 0 } } ^ { \mathrm { i } }}}, \quad \lambda^{i v}=\frac{\boldsymbol{\mu} \mathbf{y}_{\mathbf{t}}^{\mathrm{iv}}}{\boldsymbol{\mu} \mathbf{y}_{\mathbf{0}}^{\mathrm{i}}}, \quad \lambda^{e}=\frac{\boldsymbol{\mu} \mathbf{y}_{\mathbf{t}}^{\mathbf{e}}}{\boldsymbol{\mu \mathbf { y } _ { \mathbf { 0 } } ^ { \mathrm { e } }}}
$$

where $\mathbf{y}^{\mathbf{c}}, \mathbf{y}^{\mathrm{g}}, \mathbf{y}^{\mathbf{i}}, \mathbf{y}^{\mathbf{i v}}$, and $\mathbf{y}^{\mathrm{e}}$ represent the vectors of consumption, government expenditure, investment, inventory change, and exports, respectively, all in $(\mathrm{n} \times 1)$, and $\mu$ is a unit row vector $(1 \times \mathrm{n})$. So $\lambda^{c}$ is the ratio of total consumption in period $t$ over that in period 0 , and likewise of $\lambda^{g}, \lambda^{i}, \lambda^{i v}$, and $\lambda^{e}$. Moreover, $\tilde{\lambda}=\left(\lambda^{c}, \lambda^{g}, \lambda^{i}, \lambda^{i v}, \lambda^{e}\right)^{\prime}(5 \times 1)$, and $\tilde{\theta}=(\theta, \theta, \theta, \theta, \theta)^{\prime}(5 \times 1)$. Thus the first four terms in the right-hand side of equation (3) comprise the technological change effect, the next six terms comprise the effect from the final demand change, the eleventh term is the effect of economic growth and the last two terms capture interaction effect.

Equation (3) was applied to Taiwan I-O transactions tables of domestic goods and services and of import goods and services (c.i.f.) for 1986, 1991, and 1996, at 1991 constant prices, to compare the sources of demand fluctuation for total imported producer services over two periods, 1986 to 1991 
and 1991 to 1996 . All the I-O tables have thirty-nine-sector classification whereas imports are classified as goods; transportation, warehousing, and communications; financial and insurance services; food, beverage, and hotel services; business services; and other producer services.

\section{Decomposition over 1986-91}

Over the period 1986 to 1991 Taiwan's TDP grew by 45.0 percent. Had there not been any structural changes, then Taiwan's demand for imported producer services should also have grown by 45.0 percent. That is to say, $c e-$ teris paribus, economic growth in terms of final domestic product would cause imported producer services to increase by NT\$56,798 million (table 5.5). In reality, however, imported producer services increased by NT\$158,310 million, far higher than the increased value caused by TDP. Hence, economic growth accounts for only 35.9 percent of the total growth of imported producer services. The main reason Taiwan's imported producer services grew faster than TDP was the technical change in Taiwan's economy, which raised import intensity and increased by NT\$71,388 million in imported services, accounting for 45.1 percent of the total growth. However, this was offset somewhat by the substitution-effect changes in producer services of NT\$12,125 million.

In addition to the technical change factor, the increase in imported producer services was also partly due to changes in the structure of final demand. All other things being equal, a change in the structure of final demand would cause demand for imported producer services to increase by NT\$11,474 million, which accounts for 7.2 percent of the total increase in imported producer services. The main source for this change comes from the structural changes in the component elements of final demand. The interaction term for technical change and final demand would also cause an increase in imported producer services of 20.4 percent.

Viewed in terms of demand for individual services, economic growth played a more important role in increases in the import of transportation, warehousing, and communications, and of finance and insurance services by inducing more imports of goods, thus confirming the finding in section 5.2 that merchandise imports contribute significantly to increases in the import of services. If we look at subitems of these changes, we find that a change in import intensity is even more important than the factor of economic growth in contributing to the import of transportation, warehousing, and communications. Moreover, the effect of technical change on other producer services and business services is far more significant than the effect of economic growth, although it might be partly induced by economic growth itself.

The increase in imported producer services caused by the change in the structure of final demand had the greatest impact (41.3 percent) on the import of finance and insurance. Among the subitems in the changes in final 


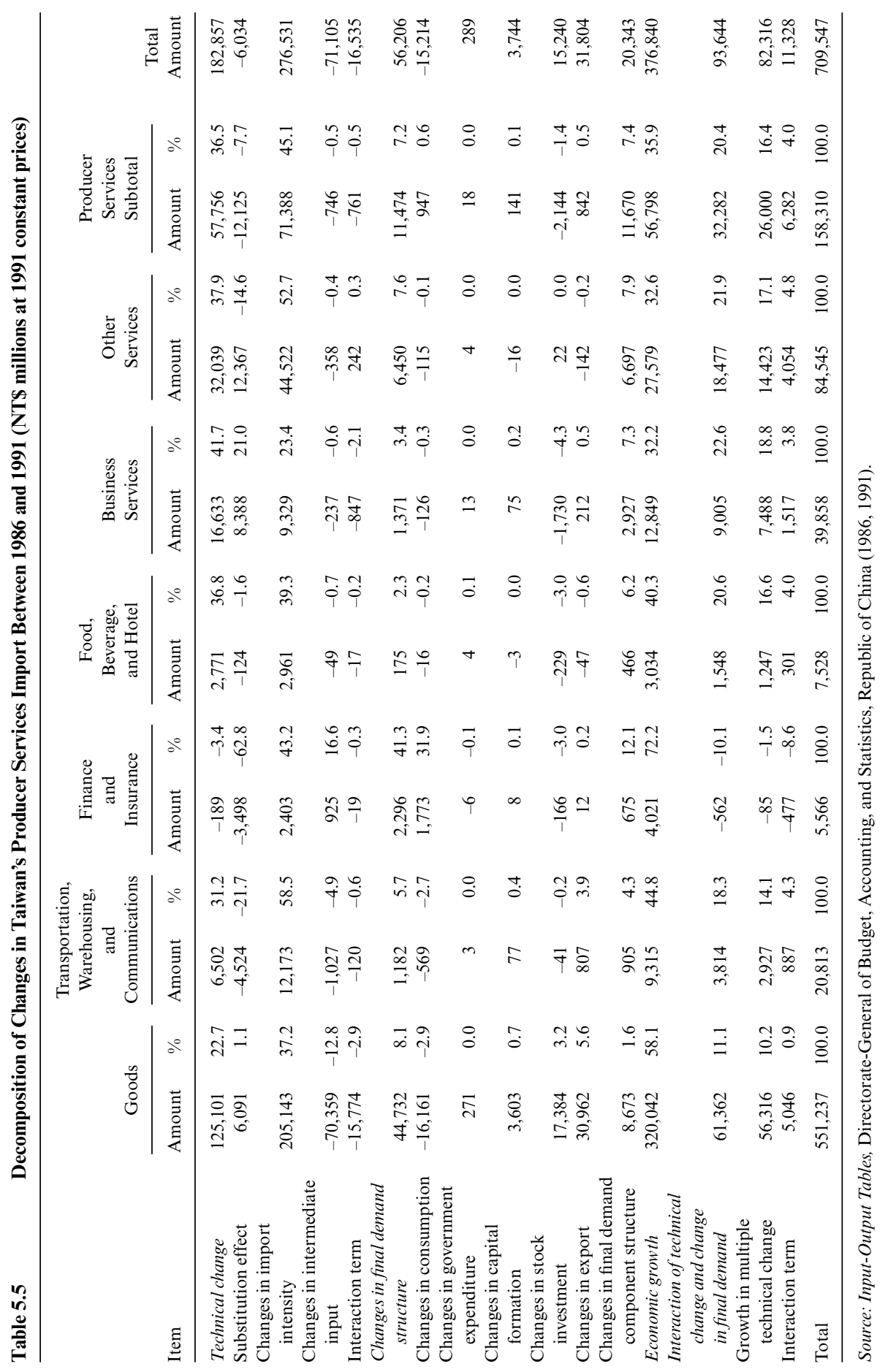


demand structure, changes in consumption (which accounted for 31.9 percent) was the most important factor.

In summary, for transportation, warehousing, and communications services; food, beverage, and hotel services; business services; and other producer services, the main sources of the increase in imports over the period 1986 to 1991 was economic growth and technical change. However, the increase in imported financial and insurance services was brought about by economic growth and changes in final demand.

\section{Decomposition over 1991-99}

Over the period 1991 to 1996, TDP in Taiwan grew by 37.9 percent. Other things being equal, imported producer services demand should have increased by NT $\$ 108,281$ million (table 5.6). However, the demand for imported producer services increased by only NT $\$ 79,819$ million, less than the rate of TDP growth. This was mainly because structural changes in final demand caused it to fall by NT $\$ 31,218$ million, which accounts for a negative 39.0 percent of the total increase in the import of producer services. Changes in the structure of the final demand component and changes in government expenditure were the main causes.

In addition, technical change led to import density change, which also caused imported producer services demand to fall by NT $\$ 23,432$ million, a negative 29.4 percent of the total increase in the import of producer services. However, substitutability between imported producer services caused demand to increase by NT\$23,234 million (29.1 percent). Furthermore, changes in the intermediate input coefficient and the interaction term have both negatively affected the demand for imported producer services. On balance, the effect of technical change reduced demand for imported producer services.

As far as individual sectors are concerned, economic growth increased demand for imported producer services in all sectors. The impact was particularly great in the other producer-services sector in terms of value and in the finance and insurance sector in terms of contributing to the rate of growth. However, as changes in technology created a fall in transportation, warehousing, and communications services; financial and insurance services; and food, beverage, and hotel services, there was a significant increase in the substitution effect for business services and other producer services. Change in import intensity had a large negative impact on import of the financial and insurance services sector and on other producer services. If one looks at the overall effect of technical change, one can see that the effects were negative for the transportation, warehousing, and communications sector; for the financial and insurance services sector; and for the food, beverage, and hotel services sector.

The main sources of import change for the transportation, warehousing, and communications sector; financial and insurance services sector; and 


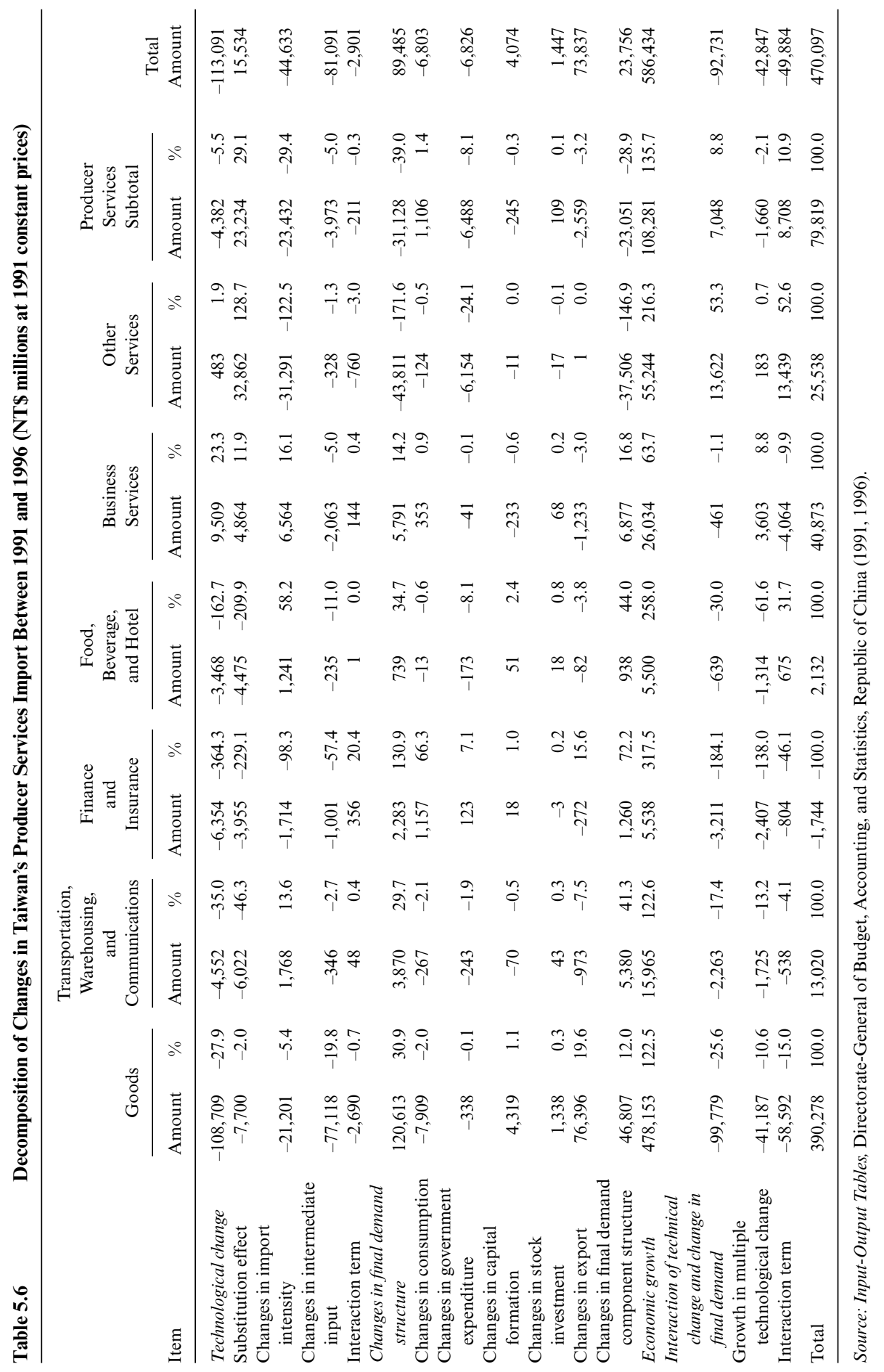


food, beverage, and hotel services sector over the period 1991 to 1996 were economic growth and structural change in final demand. For business services, the main sources of change were economic growth and technical change. For other producer services, the main sources of change were economic growth and the interaction effect between technical change and final demand. The main sources of import-service change thus differed for the various producer-services sectors. ${ }^{5}$

In conclusion, regardless of whether one looks at the period from 1986 to 1991 or from 1991 to 1996, with the exception of the financial and insurance services sector, demand has been increasing in every producer-services sector. While major changes have all been the result of economic growth, the secondary sources of change have been more diverse. In the financial and insurance services sector, in both stages, change in final demand has been the secondary source, whereas in the business-services sector it has been technical change. As far as the transportation, warehousing, and communications sector is concerned, over the period 1986 to 1991 the source of secondary changes was technical change, whereas in the period 1991 to 1996 it was change in final demand. There was a similar change in the producerservices sector where, during the period 1986 to 1991, the secondary source of changes was technical change, but during the period 1991 to 1996 it was final demand.

\subsection{Comparative Advantage and Potential Development of Taiwan's Services Trade}

The last two sections analyze the growth and determinants of Taiwan's trade in services based on national income accounts for the period 1951-99 and the sources of growth in producer services based on I-O tables for the years 1986, 1991, and 1996. To complete our analysis this section aims at examining features of service statistics as published in the official BOP, comparing the comparative advantage of service trade among several countries including Taiwan, South Korea, Singapore, and eight advanced countries based on their BOP data, and discussing the potential development of Taiwan's service exports in several specific areas.

5. We have so far left out discussion of the decomposition for imported producer goods due to our focus on imported producer services. For a comparison we also list decomposition for changes in imported producer goods that occurred between 1986 and 1991 in table 5.5 and between 1991 and 1996 in table 5.6. It is seen that the main sources of the changes were economic growth and technical change (particularly change in import intensity) during the first period, and economic growth and structural change in final demand (particularly change in export) for the second period. A major difference between imports of producer goods and services is that structural change in final demand was a positive contributor ( 30.9 percent) to increases in imported producer goods, but was a negative contributor $(-39.0$ percent $)$ to increases in imported producer services. Other than this the patterns of changes in the imported producer goods and services are quite similar. 


\subsubsection{Service Statistics as from BOP}

The BOP provides trade statistics based on actual international payments, so its coverage is not as comprehensive as that of the NIA-based statistics. Therefore, any services paid in kind or not yet paid must be estimated and included in the NIA trade statistics. Items such as transportation and insurance carried out by domestic firms for merchandise imports do not appear in the BOP but are counted as both imports and exports of services in the NIA trade statistics. However, the BOP is still the main source of services-trade data for the NIA statistics. Moreover, the BOP provides services-trade statistics by detailed category and in U.S. dollars, and which can be used for analysis of services trade for different categories and for computation of revealed comparative advantage (RCA) for comparison.

Although BOP figures differ from NIA constant-price figures as presented in table 5.1 due to coverage and changes in prices and in the exchange rate, they tend to move in tandem. As a comparison table 5.7 lists growth rates and shares of services trade as calculated from the BOP and NIA figures, respectively, for the period 1964-99. The growth rates are for five-year average annual rates while the shares refer to annual shares of service exports (imports) in their total exports (imports) of goods and services. It is seen from table 5.7 that the two sets of growth rates or shares moved together but that those based on the BOP fluctuated more widely than those based on the NIA, particularly during 1974-79, when large price changes

Table 5.7

Growth and Share of Taiwan's Total Service Trade as Computed from BOP and NIA, 1964-99 (\%)

\begin{tabular}{|c|c|c|c|c|c|c|c|c|}
\hline \multirow{3}{*}{$\begin{array}{l}\text { Selected } \\
\text { Year }\end{array}$} & \multicolumn{4}{|c|}{ BOP } & \multicolumn{4}{|c|}{ NIA } \\
\hline & \multicolumn{2}{|c|}{ Growth Rate } & \multicolumn{2}{|c|}{ Share } & \multicolumn{2}{|c|}{ Growth Rate } & \multicolumn{2}{|c|}{ Share } \\
\hline & EX & IM & EX & IM & EX & IM & EX & IM \\
\hline 1964 & & & 10.5 & 14.6 & & & 11.2 & 13.8 \\
\hline 1969 & 32.3 & 27.0 & 16.1 & 17.4 & 33.5 & 27.0 & 17.3 & 17.5 \\
\hline 1974 & 26.6 & 23.6 & 10.8 & 13.3 & 19.3 & 20.6 & 15.3 & 17.1 \\
\hline 1979 & 20.8 & 22.3 & 9.9 & 15.7 & 14.5 & 17.2 & 14.8 & 22.4 \\
\hline 1984 & 7.3 & 14.6 & 7.5 & 20.1 & 6.3 & 11.8 & 12.1 & 29.2 \\
\hline 1989 & 23.7 & 20.5 & 9.8 & 21.3 & 11.6 & 10.6 & 12.0 & 24.6 \\
\hline 1994 & 13.1 & 9.2 & 12.5 & 20.7 & 8.1 & 8.6 & 13.0 & 24.2 \\
\hline 1999 & 2.1 & 3.1 & 10.8 & 18.8 & 4.0 & 4.8 & 10.8 & 20.8 \\
\hline
\end{tabular}

Source: Balance of Payments, Central Bank (various issues); National Income Statistics, DirectorateGeneral of Budget, Accounting, and Statistics, Republic of China (various issues).

Notes: $\mathrm{BOP}=$ balance of payments; NIA = national income accounts; $\mathrm{EX}=$ exports of services; $\mathrm{IM}=$ imports of services. Growth rate is five-year average rate; share is service trade as a percentage of total exports or imports of goods and services. Blank cells represent starting year. 
occurred worldwide, and during 1984-94, when there was sharp appreciation of the New Taiwan dollar against the U.S. dollar.

To examine detailed categories of services trade as provided by the BOP, data on exports and imports of services are listed in table 5.8 for transportation, travel, and other services for the period 1984-99. Several observations can be made from table 5.8:

1. Passenger services. Exports grew substantially between 1984 and 1994 before beginning to decline from 1995 onward. However, imports maintained a growth trend throughout this period, and thus the deficit in passenger services has enlarged in recent years. In 1999, the value of exports was US $\$ 486$ million while imports were almost three times as large, amounting to US\$1,324 million.

2. Freight services. The level of exports and imports is more balanced. Both imports and exports grew very rapidly between 1984 and 1994, with the growth in exports being faster than that of imports. The value of exports outweighed that of imports for several years in the mid-1990s. However, there has been a slight decline in recent years in the level of both imports and exports.

3. Other transport services. These include seaport and airport services, cargo handling, maintenance and repair of aircraft, and others. The trade balance has been in deficit, with import values being around four to six times the level of export values.

4. Business and personal travel. Both business and personal travel in Taiwan grew rapidly between 1984 and 1994 but declined slightly after 1996 due to the Asian financial crisis. The trade deficit has been large for both business and personal travel throughout 1984 and 1999. In 1999 the import of business travel was about twice that of the export, at US\$2,222 million and US\$1,238 million, respectively, whereas the import of personal travel was more than twice that of the export, at US\$5,176 million and US\$2,324 million, respectively.

5. Other services. These include communications, financial, computer and information, and other business services, which are the fastest growing areas of the service trade. ${ }^{6}$ As indicated in table 5.8, other services in Taiwan grew rapidly for both imports and exports between 1984 and 1994, with the import amount being greater than the export. Export growth between 1989 and 1994 was much faster than that of imports, so the gap between imports and exports narrowed in the mid-1990s. However, exports started to decline in 1998 and 1999, while imports continued to grow (although at a slower pace) after 1994. In this area, then, the trade deficit has

6. As proposed by the International Monetary Fund in 1994, Taiwan adopted the new method in 1996 to provide more detailed information on trade in other services and traced data back to 1984. 


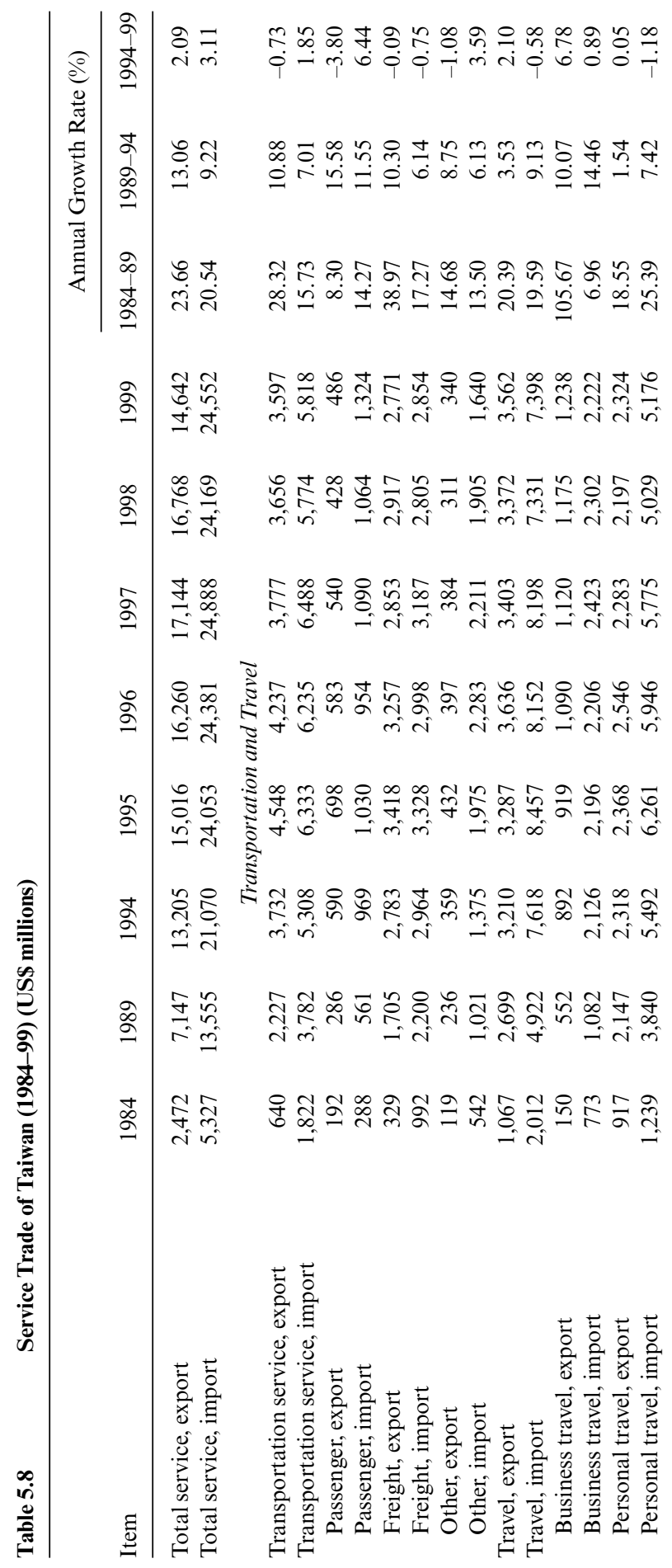




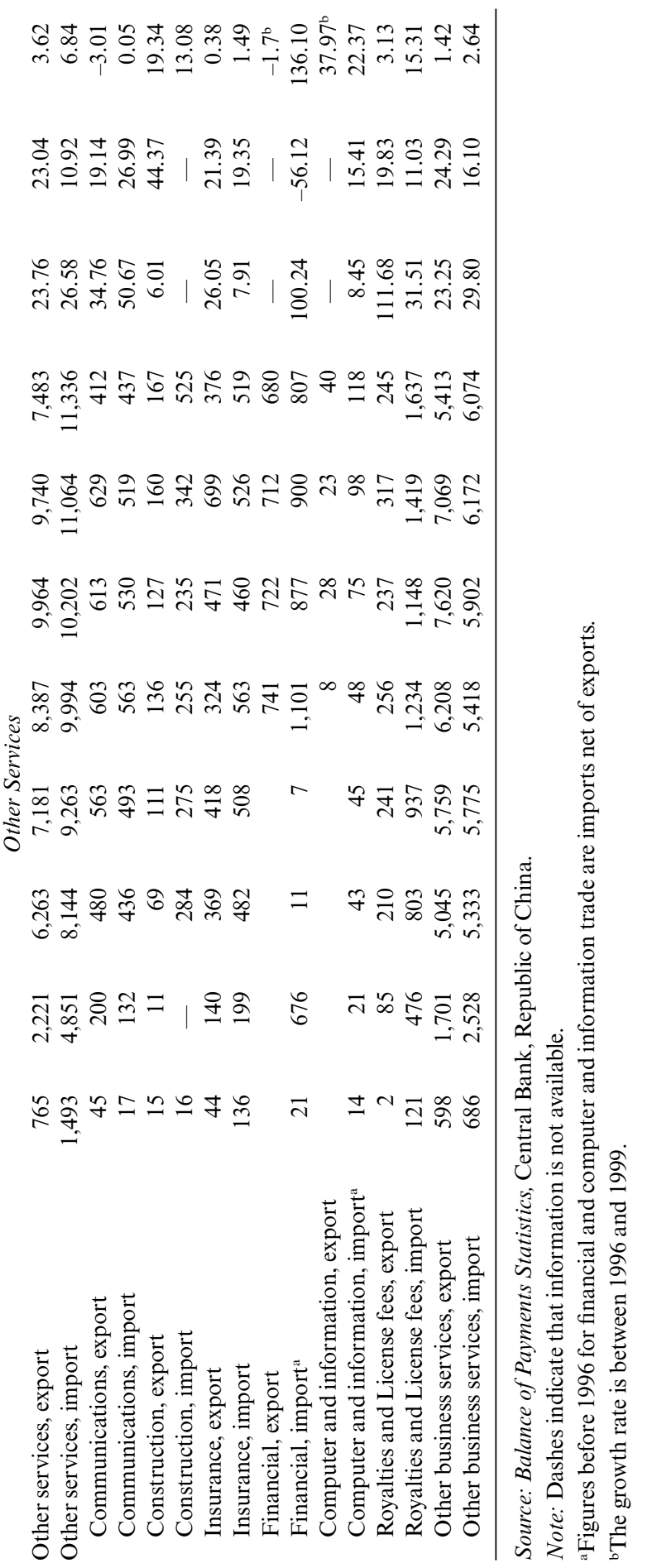


grown in recent years. Among the individual items of other services, communications, insurance, and other business services have a relatively balanced trade flow in Taiwan, while in construction, finance, computers and information, and particularly royalties and license fees, the trade flow has clearly favored imports rather than exports.

In summary, according to the BOP statistics, Taiwan's total exports of services grew at an annual average rate of 23.7 percent during 1984-89, 13.1 percent during 1989-94, and 2.1 percent during 1994-99, as compared with the annual average rates of 20.5 percent, 9.2 percent, and 3.1 percent, respectively, in total imports of services for the three periods. The growth of service exports was faster than that of service imports before 1994 mainly because the service exports started from a much smaller base. As table 5.8 indicates, the imports actually exceeded the exports every year by more than 44 percent and incurred a large deficit throughout the period. In fact, the deficit existed almost every year for all categories of services. One eyecatching services category in this table is royalties and license fees, whose import has increased rapidly because of the development of hi-tech industries by Taiwan (with the amount reaching US\$1,637 million in 1999) but whose export has remained stagnant in recent years (with the amount totaling only US\$245 million for the same year). The weak position of Taiwan's trade in services seems to attest to its lack of comparative advantage in exports of services, to which we now turn.

\subsubsection{Comparative Advantage of Services Trade among Countries}

Balassa (1965) proposed an RCA index to measure the relative advantage of a trade product for a country to export to the rest of the world. This index can be applied to services trade for Taiwan and a number of other countries for comparison. For an $i$ th country and $j$ th service, the index is given by

$$
\mathrm{RCA}_{i j}=\frac{\mathrm{E}_{i j} / \mathrm{TE}_{i}}{\mathrm{WE}_{j} / \mathrm{WTE}},
$$

where $\mathrm{E}_{i j}$ is the export value of service $j$ of the $i$ th country, $\mathrm{TE}_{i}$ is the total export of goods and services of the $i$ th country, $\mathrm{WE}_{j}$ is the world total export of service $j$, and WTE is the world total export of goods and services.

Table 5.9 lists yearly RCA indexes of total services, transportation, and other services for eleven countries from 1992 to 1998. It shows that the RCA index of total services has values less than 1 for Taiwan, Japan, Korea, Singapore, Canada, and Germany and has values greater than 1 for the United States, the United Kingdom, the Netherlands, France, and Italy, and this pattern was maintained throughout the 1990s. This shows that developed countries, except Japan, Canada, and Germany, have a clear advantage over Asian newly industrialized economies (NIEs) in services trade. The difference in the RCA indexes between countries probably can be partially ex- 
Table 5.9

Index of Revealed Comparative Advantage of Service Trade

\begin{tabular}{|c|c|c|c|c|c|c|c|}
\hline Country & 1992 & 1993 & 1994 & 1995 & 1996 & 1997 & 1998 \\
\hline \multicolumn{8}{|c|}{ Total Service Export } \\
\hline Taiwan & 0.54 & 0.64 & 0.61 & 0.61 & 0.62 & 0.62 & 0.65 \\
\hline United States & 1.36 & 1.35 & 1.38 & 1.39 & 1.40 & 1.38 & 1.39 \\
\hline Japan & 0.62 & 0.62 & 0.64 & 0.67 & 0.73 & 0.73 & 0.71 \\
\hline The Netherlands & 1.06 & 1.10 & 1.14 & 1.10 & 1.12 & 1.19 & 1.17 \\
\hline United Kingdom & 1.19 & 1.17 & 1.19 & 1.23 & 1.21 & 1.26 & 1.33 \\
\hline Korea & 0.59 & 0.65 & 0.74 & 0.79 & 0.77 & 0.80 & 0.78 \\
\hline Canada & 0.64 & 0.61 & 0.62 & 0.61 & 0.63 & 0.62 & 0.62 \\
\hline France & 1.38 & 1.43 & 1.21 & 1.18 & 1.15 & 1.12 & 1.09 \\
\hline Germany & 0.66 & 0.69 & 0.65 & 0.69 & 0.71 & 0.70 & 0.66 \\
\hline Italy & 1.19 & 1.12 & 1.08 & 1.06 & 1.04 & 1.10 & 1.08 \\
\hline Singapore & 0.94 & 0.91 & 0.94 & 1.03 & 0.97 & 0.98 & 0.71 \\
\hline \multicolumn{8}{|c|}{ Transportation Export } \\
\hline Taiwan & 0.60 & 0.65 & 0.73 & 0.78 & 0.72 & 0.62 & 0.64 \\
\hline United States & 1.25 & 1.21 & 1.20 & 1.23 & 1.22 & 1.16 & 1.09 \\
\hline Japan & 0.98 & 0.94 & 0.94 & 0.99 & 1.03 & 1.03 & 1.09 \\
\hline The Netherlands & 1.87 & 1.89 & 1.87 & 1.87 & 2.01 & 2.17 & 2.05 \\
\hline United Kingdom & 1.12 & 1.09 & 1.10 & 1.09 & 1.10 & 1.11 & 1.15 \\
\hline Korea & 1.02 & 1.16 & 1.36 & 1.36 & 1.28 & 1.51 & 1.46 \\
\hline Canada & 0.56 & 0.53 & 0.53 & 0.53 & 0.54 & 0.55 & 0.53 \\
\hline France & 1.15 & 1.24 & 1.16 & 1.22 & 1.23 & 1.20 & 1.18 \\
\hline Germany & 0.68 & 0.72 & 0.69 & 0.70 & 0.73 & 0.73 & 0.73 \\
\hline Italy & 0.88 & 0.86 & 0.81 & 0.79 & 0.76 & 0.79 & 0.77 \\
\hline Singapore & 0.67 & 0.66 & 0.69 & 0.75 & 0.74 & 0.75 & 0.77 \\
\hline \multicolumn{8}{|c|}{ Other Service Export } \\
\hline Taiwan & 0.67 & 0.87 & 0.72 & 0.71 & 0.77 & 0.83 & 0.88 \\
\hline United States & 1.13 & 1.11 & 1.25 & 1.24 & 1.26 & 1.27 & 1.36 \\
\hline Japan & 0.82 & 0.85 & 0.91 & 0.97 & 1.05 & 1.02 & 0.97 \\
\hline The Netherlands & 1.09 & 1.21 & 1.30 & 1.19 & 1.19 & 1.24 & 1.24 \\
\hline United Kingdom & 1.47 & 1.40 & 1.49 & 1.49 & 1.49 & 1.59 & 1.68 \\
\hline Korea & 0.48 & 0.51 & 0.60 & 0.66 & 0.71 & 0.68 & 0.56 \\
\hline Canada & 0.72 & 0.71 & 0.72 & 0.70 & 0.73 & 0.70 & 0.69 \\
\hline France & 1.78 & 1.82 & 1.30 & 1.21 & 1.13 & 1.05 & 1.01 \\
\hline Germany & 0.63 & 0.68 & 0.67 & 0.78 & 0.83 & 0.80 & 0.77 \\
\hline Italy & 1.23 & 1.05 & 0.93 & 0.92 & 0.91 & 0.98 & 0.97 \\
\hline Singapore & 1.12 & 1.10 & 1.22 & 1.42 & 1.33 & 1.40 & 0.82 \\
\hline
\end{tabular}

Source: Balance of Payments Year Book, IMF (1999).

plained by the stage of development in their service industries as measured by the share of service production in GDP. Take average figures of three years (1993, 1995, and 1997) for demonstration. A pair of numbers (the first for RCA index and the second for service-sector share in GDP) for each of these eleven countries is as follows: United States $(1.37,72)$, France $(1.25$, $70)$, United Kingdom $(1.22,66)$, the Netherlands $(1.13,70)$, Italy $(1.09,66)$, Singapore $(0.97,64)$, Korea $(0.75,50)$, Germany $(0.69,62)$, Japan $(0.68,59)$, 
Table 5.10

Balance of Trade in Services (US\$ millions)

\begin{tabular}{lrrrrrrr}
\hline Country & 1992 & \multicolumn{1}{c}{1993} & 1994 & \multicolumn{1}{c}{1995} & 1996 & 1997 & 1998 \\
\hline Taiwan & $-9,128$ & $-7,896$ & $-7,865$ & $-9,037$ & $-8,121$ & $-7,744$ & $-7,401$ \\
United States & 57,300 & 60,770 & 65,740 & 74,340 & 85,050 & 89,980 & 80,700 \\
Japan & $-43,960$ & $-43,080$ & $-48,060$ & $-57,350$ & $-62,240$ & $-54,150$ & $-49,420$ \\
The Netherlands & 265 & 676 & 1,411 & 2,262 & 3,835 & 5,756 & 5,201 \\
United Kingdom & 9,910 & 9,890 & 10,000 & 14,050 & 13,960 & 20,340 & 20,290 \\
Korea & $-2,884$ & $-2,126$ & $-1,801$ & $-2,979$ & $-6,179$ & $-3,200$ & 628 \\
Canada & $-10,812$ & $-10,418$ & $-8,146$ & $-7,345$ & $-6,433$ & $-6,563$ & $-4,755$ \\
France & 19,378 & 16,861 & 19,512 & 17,973 & 16,254 & 17,493 & 18,705 \\
Germany & $-27,721$ & $-31,538$ & $-39,021$ & $-45,362$ & $-44,018$ & $-41,294$ & $-42,978$ \\
Italy & $-4,438$ & 50 & 1,448 & 6,569 & 8,055 & 7,764 & 4,170 \\
Singapore & 6,551 & 7,413 & 10,014 & 12,056 & 10,255 & 11,095 & 330 \\
\hline
\end{tabular}

Source: Balance of Payments Yearbook, IMF (1999).

Taiwan $(0.62,60)$, and Canada $(0.61,64) .^{7}$ These figures clearly show that countries with RCA values greater than 1 tend to have higher service-sector shares than do those with RCA values greater than 1 tend to have higher service-sector shares than do those with RCA values smaller than 1. Among them, the United States, France, and the Netherlands have service-sector shares higher than 70 percent in GDP, whereas Asian countries, Germany, and Canada have service-sector shares lower than 65 percent. The two variables are highly correlated, with their coefficient of correlation equal to 0.75 .

Moreover, data (table 5.10) also indicate that countries with high RCA values (such as the United States, France, the United Kingdom, the Netherlands, and Italy) tend to have surpluses in services trade, whereas those with low RCA values (such as Korea, Germany, Japan, Taiwan, and Canada) tend to have deficits in services trade. Singapore is a country in the margin, having an RCA value near 1 in total services but a surplus in services trade. This is probably because Singapore has an RCA value much greater than 1 in other services. The RCA index and the balance of services trade across the eleven countries are actually highly correlated, with the correlation coefficient equal to 0.79 , again in three-year averages for 1993, 1995, and 1997. The correlation coefficient between balance of trade in services and service-sector share is also as high as 0.59 . The high correlation between RCA index and GDP share of service industries, and between RCA index and balance of trade in services, is consistent with our finding in section 5.2 that service-sector share has a positive effect on services export but a negative effect on services import.

As shown in table 5.9, the RCA index of transportation or other services follows a pattern similar to that of total services, with a few exceptions. The

7. RCA index numbers are taken from table 5.9 and shares in percent are from various issues of the World Development Report by World Bank. 
United States, the Netherlands, the United Kingdom, and France had maintained high RCA status throughout the period 1992-98 in both transportation and other services, but the index for Italy was less than 1 in both categories except for the years 1992 and 1993 in other services. Japan's index exceeded 1 in recent years in both categories, whereas Korea saw values much higher than 1 throughout the period in the category of transportation. Another exception is for Singapore, whose index had greatly exceeded 1 in the category of other services for the entire period other than 1998, a year when the Asian financial crisis broke out. The remaining countries are all having the value of the index less than 1 throughout the period.

Similar to Canada, the RCA index of Taiwan ranks low among the countries listed in table 5.9 either in total services, in transportation, or in other services. The index had never exceeded 0.65 in total services, 0.78 in transportation, and 0.88 in other services during the period from 1991 to 1998. Taiwan therefore had unfavorable exports of services and still has a large deficit in services trade. However, its RCA index appears to show signs of slight improvement in recent years, as can be seen from table 5.9.

\subsubsection{Potential Development of Taiwan's Export Services Trade}

To conclude this section, we discuss the potential development of some important export services in the areas of transportation, communications, and business services. Related government policies are also addressed.

\section{Transportation}

In a study of the flow of trade among developed and developing countries, Langhammer (1989) argued that developing countries had better positions in developing factor-enriched services, such as ocean transportation and travel, than in developing knowledge-based services. Taiwan's freight trade development seems to be a case in point. Its freight exports caught up with imports in the early 1990s because Taiwan's abundant capital and fastgrowing foreign trade throughout the 1980s provided excellent opportunities for ocean freight services to develop. However, further development of freight services was restrained because a large proportion of Taiwan's export-oriented, labor-intensive manufacturing firms had moved their operations to mainland China, and direct shipping between the mainland China and Taiwan are still not permitted by the government.

In air transportation, during the last decade, a new Taiwanese airline, EVA, joined China Airlines in the operation of international flights. However, due to Taiwan's very limited official diplomatic relationships around the world, negotiations aimed at expanding flight routes have been so difficult as to limit the growth of these two airlines.

With Taiwan geographically placed at the center of the East Asian countries, the distance to other major East Asian cities can be minimized via Taipei. To make use of this locational advantage, since 1995 Taiwan's gov- 
ernment has been pursuing plans to develop Taiwan into a regional sea and air transportation center. These plans are part of a bigger project, which aims to transform Taiwan into an Asia Pacific Regional Operations Center (APROC). For sea transportation the goal is to make Taiwan an East Asian hub for container transshipment, and efforts have been made to improve the efficiency of container handling, custom processing, and other details in pursuit of this plan. Some existing port services were privatized and liberalized to allow foreigners to participate. Most important, to overcome the ban of nondirect shipping to mainland China, an offshore shipping center has been set up in Kaohsiung harbor to handle goods transshipped to and from mainland China. According to the government's review (Council for Economic Planning and Development [CEPD] 1999), the volume of container handling at Kaohsiung harbor increased by 27 percent between 1994 and 1998.

As for the air transportation center, due to the government's effort in improving facilities and deregulation, an air freight transit hub is already taking shape. United Parcel Service (UPS) established its regional headquarters at CKS International Airport in 1996 and Federal Express (FedEx) has also expanded its operations at the airport.

\section{Communications}

As in many other countries, the communications industry in Taiwan has long been a monopolistic public enterprise and the liberalization process has just begun in recent years. The most significant change was the opening of the market to private cellular phone services in 1997, when eight new licenses were issued, including two licenses covering the whole of Taiwan and 6 licenses for regional coverage. In the last two years the market penetration rate of cellular phones grew enormously, from less than 20 percent to more than 50 percent. Foreign technology and foreign capital participated actively in this market opening and almost every new entrant to the market came in the form of a joint venture of a local enterprise and a world-famous communications giant, such as AT\&T, GTE, Sprint, or others. Foreign firms will be allowed to invest up to 20 percent when Taiwan joins the WTO. The fixed net service (local phone services) was also opened to private entry (with three licenses being issued in March 2000) and to the participation of foreigners similar to that of the cellular phone services. At this stage Taiwan is still a net importer in the area of communications.

\section{Business Services}

Business services in Taiwan flourished with the rapid growth of manufacturing industries, and the growth of foreign direct investment (FDI) in Taiwan's manufacturing industries was also accompanied by foreign business services. The most significant services are advertising and accounting. In 1997, for example, among the 36 largest advertising companies in Taiwan, 10 companies were solely owned by foreigners and 12 were joint ven- 
tures between local and foreign providers. Foreign advertising services came into Taiwan's market initially with multinational firms that produced and marketed consumer products in Taiwan, and gradually began providing services to local consumer-product producers. They provided services first by cooperating with local firms and then either through the formation of joint ventures with local firms or by buying up local firms. Foreign advertising companies brought in new technologies and different business practices and have totally revolutionized this industry in the last decade.

In recent years, Taiwan's advertising companies have also begun to export their services, accompanying Taiwan's FDI, to other developing countries, with mainland China being the most prominent destination.

The accounting industry in Taiwan is also very internationalized even though some areas of accounting services are restricted to performance by only locally certified public accountants. World leading accounting firms, such as PriceWaterhouseCoopers, Arthur Andersen, and KPMG, have all established their operations in Taiwan mostly by acquiring existing Taiwanese accounting firms. Local independent accounting firms also seek to be members of an international accountants' group or confederation in order to meet the increasing needs of local firms for globalization. Taiwan's accounting firms are also beginning to provide services to Taiwanese businesses that have invested in mainland China.

In the area of business consulting services, engineering consulting services, technical services, and design services, local firms have been dominated by small and medium-sized enterprises and foreign presence has not been as prominent as in the advertising and accounting service industries. Foreign service providers operate mainly through the presence of natural persons for a short period of time rather than by establishing a permanent branch. This is probably because the scale of economy in these various areas is smaller and a large foreign firm may not be as competitive as local small firms. They may also cooperate with local firms on a case-by-case basis (Hsueh, Tu, and Wang 1995; Hsueh and Tu 1999).

In the legal services industry, foreign legal service providers can form a cooperative relationship with licensed lawyers in Taiwan except in the form of a joint liability and profit-sharing arrangement. The government will grant recognition of "attorney of foreign legal affairs" (AFLA) after Taiwan enters the WTO. Most importantly, AFLA will be allowed to establish partnerships with or employ locally licensed lawyers three years after Taiwan gains accession into the WTO. Thus we can expect that trade in legal services in Taiwan will increase in the near future.

\subsection{Conclusion}

In this paper we employ trade data from the NIA, the I-O tables, and the BOP to examine Taiwan's trade in services and its future development. Our 
analysis is very much limited by the availability and accuracy of the trade data on services. Unlike the trade in goods, which is registered through customs ports and produces abundant information, data on the services trade come mainly from records on foreign exchange transactions provided by the central bank in the BOP and are not comprehensive. The statistics on services trade in the NIA, which are based on the BOP and other information, are comprehensive but far too aggregate; they lack information on detailed components. In particular, information on the services trade is not available in constant prices except for the aggregate imports and exports of services exclusive of the merchandise transport and insurance. This makes our comparison over time difficult. Thus, provision of more information on the services trade should be improved and built on a common framework to facilitate comparisons over time and among countries.

Both NIA and BOP statistics demonstrate that Taiwan's trade in services has grown faster than its trade in goods and that service imports have also grown faster than service exports in the past forty years. In fact, Taiwan's trade in services has constantly been in deficit. This may be partly explained by the regression result of this research, which shows that Taiwan's exports of services are income inelastic but price elastic, whereas its imports of services are income elastic but price inelastic. Our regression result also indicates that expansion of domestic service-sector share contributes positively to balance of trade in services both by reducing imports of services and by increasing exports of services. The relatively weak position in Taiwan's services trade can also be seen from the comparison of revealed comparative advantage indexes or services-sector share between developed countries and Asian NIEs. This suggests that Taiwan needs to improve its position of comparative advantages in trade in services by strengthening its service sector.

As shown in the I-O tables, services used by the producing sector accounted for more than two thirds of the imported services in 1996. A complex decomposition analysis reveals that in the 1986-91 period, import coefficient changes and economic growth contributed most to the growth in imported producer services. However, in the 1991-96 period, import coefficient changes and change in final demand structure both contributed negatively to its growth, with the source of growth mainly coming from economic growth.

Our analysis also shows that in the individual services sector, no matter whether in transportation, communications, financial services, or business services, the trade balance has also been in deficit. As part of the overall commitment to WTO accession, commitment to the market opening of various service sectors will increase the import of services in the near future. However, with the increase in Taiwan's FDI toward other countries and the continued growth of service-sector GDP share, Taiwan's service sector will have good potential for export growth. Hence Taiwan's trade in services is likely to achieve substantial growth in the future. 


\section{References}

Balassa, Bela. 1965. Trade liberalization and "revealed" comparative advantage. Manchester School of Economic and Social Studies 33:99-123.

Central Bank. Various issues. Balance of payments. Taipei: Central Bank, Republic of China.

. Various issues. Financial statistics. Taipei: Central Bank, Republic of China.

Council for Economic Planning and Development (CEPD). 1999. The performance and prospect of the Asian Pacific regional operations center project (in Chinese). Taipei: CEPD.

Department of Commerce. Various issues. Statistical abstract of the United States. Washington, D.C.: Department of Commerce.

- Various issues. Survey of current business. Washington, D.C.: Department of Commerce.

Directorate-General of Budget, Accounting, and Statistics. Various issues. Inputoutput tables. Taipei: Directorate-General of Budget, Accounting, and Statistics.

. Various issues. National income statistics. Taipei: Directorate-General of Budget, Accounting, and Statistics.

Han, X. 1995. Structure change and labor requirement of the Japanese economy. Economic System Research 7 (1): 47-65.

Hsueh, L., and Y. Tu. 1999. The competitive advantage of the business service industry in Taiwan (in Chinese). Chung-Hua Institution for Economic Research's Economic Papers no. 187. July. Taipei: Chung-Hua Institution for Economic Research.

Hsueh, L., Y. Tu, and S. Wang. 1995. The development and prospect of producer service industries in Taiwan: An international comparison (in Chinese). Chung-Hua Institution for Economic Research Contemporary Economic Issues Series, no. 2. Taipei: Chung-Hua Institution for Economic Research.

International Monetary Fund (IMF). 1999. Balance of payments yearbook. Washington, D.C.: IMF.

Langhammer, R. J. 1989. North-south trade in services: Some empirical evidence. In Services in world economic growth symposium, ed. H. Giersch, 248-71. Tübingen, Germany: Mohr.

World Bank. Various issues. World development report. Washington, D.C.: World Bank.

\section{Comment Philippa Dee}

The paper uses three different data sets to explore the growth potential of Taiwan's trade in services. These are as follows:

- Time-series national accounts data to econometrically estimate the determinants of Taiwan's service imports and exports over time

- Input-output data for three separate years to decompose the growth of Taiwan's total imports of producer services into the components aris-

Philippa Dee is assistant commissioner at the Productivity Commission, Australia. 
ing from (a) changes in the intensity of imported service use in each producing industry and (b) changes in industrial structure

- Balance-of-payments data for a range of years to calculate indexes of revealed comparative advantage for Taiwan's services, to compare with similar indexes for other economies.

Together, the separate pieces of analysis paint an interesting picture of the role of services in economic development. I have some specific comments on particular aspects of the analysis, and some general comments about the broad themes of the paper.

Any researcher who has worked in the services area is aware of the difficulty of obtaining good primary data. Accordingly, I would like to know more about the data sources used, and the properties of some of the data.

First, it would help to know whether all three data sets were derived independently, or whether the national accounts and input-output data ultimately come from balance of payments sources. Such clarification would help to establish the information-richness of the data.

Second, it would help to know whether each of the three input-output tables were based on independent surveys of firms' costs and sales structures, or were imputed from surveys for other years. The reader can have greater confidence in the growth decomposition if it uses input-output data based on separate surveys.

Third, it would help to know about the time-series properties of the national accounts data used for the econometric estimation. If the data are stationary, then the estimation techniques and methods of statistical inference used by the authors are appropriate. If, however, the data are not stationary (in the sense of containing unit roots), as is likely, then it is not clear that the authors have used the appropriate techniques. If the residuals from their estimating equations are themselves not stationary, the regressions they present are spurious. If the relationships they present are genuine cointegrating relationships between nonstationary variables, the authors do not appear to have used the appropriate tests of statistical significance.

Further elaboration on a few of the econometric results would be useful. The authors note that Taiwan's exports of services seem to depend negatively on Taiwan's per capital income. The authors offer no interpretation, but the result could indicate that Taiwan's service exporters seek out foreign markets more vigorously when the growth in domestic demand slows. As the authors note, however, a more conventional economic specification would include foreign rather than domestic income as a determinant of Taiwan's service exports.

The finding that higher tariffs in manufacturing help raise exports of services is also puzzling. It is at odds with conventional economic analysis, in which tariffs in manufactures act as a tax on the exports of other sectors, either because other sectors use manufactures directly as inputs, or because 
import protection for manufacturing leads to a real appreciation of the exchange rate.

In the input-output analysis, it is not always clear whether the service input requirements being reported are direct requirements, or total (direct and indirect) requirements. Although most of the analysis seems to report direct requirements, an interesting piece of additional analysis would be to compute, for each sector of the economy, the direct and indirect service input requirements per unit of final demand. Since one particular category of final demand is exports, the computation would reveal how important an indirect role services have played in Taiwan's recent and phenomenal nonservice export performance.

The paper has a really interesting underlying theme about the complementarity between production services and other sectors of the economy. The authors highlight that merchandise exports need transport services to be shipped around the world. The complementarities extend beyond that, however. Every business needs banking services. Every business needs telecommunications services. The facilitation (or margins, in input-output terminology) role of services extends well beyond transport.

The complementarities show up in the econometric results, where services imports increase as goods imports increase, where services exports increase as goods exports increase, and where services exports increase as services output increases.

The complementarities also show up in the increasing service import intensity of other (nonservice) activities. It is a very interesting finding that this is not due to changes in the sectoral composition of activity, but instead due to economic growth and technical change.

Here, however, it is important to understand why the technical change in favor of imported service inputs appears to be reversed over 1991-96. Is this a temporary phenomenon, a statistical artifact (perhaps due to some subtle classification change), or a permanent feature?

It would also be useful to know whether the longer term technical change in favor of imported services is because Taiwanese businesses are contracting out activities that they previously undertook in-house.

The complementarities show up finally in the stories told about the prospects for Taiwan's services industries in the future. By focusing on measures of revealed comparative advantage based on measures of cross-border trade, the authors (I suspect) paint too bleak a picture of Taiwan's future service export prospects. This is because the indexes of revealed comparative advantage are based on data that ignore services delivered via commercial presence. In the same way that U.S. advertising firms came to Taiwan to support U.S. manufacturing multinationals, perhaps Taiwanese service firms are moving offshore to support Taiwan's outbound manufacturing foreign direct investment (FDI). Any evidence on this, either anecdotal or via survey, would be extremely useful. There are theoretical an- 
tecedents for this view. Conventional trade theory has already noted possible complementarities between trade in goods and trade in capital, when the goods trade is motivated by things other than differences in factor intensities (i.e., other than comparative advantage, narrowly defined). I think similar reasoning can support complementarities between trade in manufactures and trade (via FDI or cross-border) in services.

\section{Comment Mario B. Lamberte}

The paper first discussed Taiwan's economic growth rate over the period 1951-99, which is impressive by international standards, and the rapid structural change in the country's economy, particularly the shift from an agrarian economy to a services-dominated economy. As the authors have noted, Taiwan's external trade in services has increased rapidly as its entire services sector has expanded. The paper shows that, in general, Taiwan is quite strong when it comes to exports of goods but remains weak when it comes to exports of services. Thus, its trade in services has been in deficit during the period of analysis. Incidentally, the Filipino contract workers in Taiwan in a way have contributed to that deficit. My comments on the paper are organized around five main points, as follows.

\section{Policy Environment for the Services Sector}

It would greatly help the readers appreciate the results of the descriptive and econometric analyses if the authors discussed at the outset the changes in the policy environment for the services sector. Although this is somewhat alluded to in section 5.2 of the paper, a much more extended discussion of the policy environment is needed.

\section{Descriptive Analysis}

Regarding the analysis on import and export of services, it might be worthwhile to add information on the sources of import of services and destination of export of services of Taiwan. My interest lies on the extent of trade in services between Taiwan and other Asian countries. This may also help the authors make some qualifications to their observation that Taiwan is quite weak in its export of services. I suspect that its export of services to Asia is relatively large.

\section{Determinants of Trade in Services}

The authors have examined the determinants of Taiwan's trade in services. They concluded that "trade in goods, per capita income, and the

Mario B. Lamberte is president of the Philippine Institute for Development Studies (PIDS). 
relative price of services are three important determinants of the services trade." The authors have included as explanatory variables nominal exchange rate and effective tariff rate, which is defined as the ratio of total import tariff revenues to total custom imports, to reflect changes in government policies. These may not capture entirely the government's policies for the services sector during the period of analysis. I think the authors must find a way of incorporating in their model nontariff barriers, which could have affected the dependent variables during the period of analysis. This is why a discussion about the policy framework at the very start of the paper would be greatly useful.

I am not convinced that the effective tariff rate, as defined in the paper, is a good candidate for an explanatory variable in the exports of services equations. Usually, countries do not impose tariffs on their exports of goods and services. What is more worrisome is that the result shows that the effective tariff rate has a significant, positive effect on exports of services. It means that raising the tariff on trade in services can boost Taiwan's exports of services!

There may also be a simultaneity problem in the model. For instance, growth in imports of services, which is an independent variable in the model, could have been affected by the relative price of imports and the nominal exchange rate. The same can be said of the growth in export services.

The use of Taiwan's per capita income as proxy for per capita income for the rest of the world is, I think, not appropriate. I suggest that the authors use the weighted average per capita income of Taiwan's major trading partners, which can be easily obtained from publications of multilateral agencies.

\section{Intensity of Import Services}

The data in table 5.7 about the intensity of import services of Taiwan are interesting. I expected the trends in import intensities of the thirty nine sectors to behave in a more stable manner, going up or down. However, I notice significant fluctuations in import intensities between 1986 and 1996. For instance, import intensities of trade, real estate, travel services, and business significantly dropped in 1991. There must be some explanation for these fluctuations.

One thing that seems surprising is the sharp rise in the import intensity of electricity between 1991 and 1996. How can such a phenomenal rise be explained?

\section{Relative Comparative Advantage}

That Asian economies are shown to have weak comparative advantage in trade in services today is not surprising at all. However, the authors should also emphasize the fact that the computed revealed comparative advan- 
tages (RCAs) of some Asian economies, including that of Taiwan, have been increasing during the period of analysis. This can be observed in certain sectors such as transportation. This may have occurred when Asian economies gradually liberalized their services sectors. As Asian economies deepen and broaden the liberalization of their services sector, further improvement of their RCAs can be expected. This is perhaps what the authors expected of Taiwan upon accession to the World Trade Organization. 